\title{
ANALISIS KEPUASAN PELANGGAN TERHADAP KUALITAS LAYANAN OJEK ONLINE (WAKJEK) DI KOTA BATAM
}

\author{
Yovan Sawir Saputra, Shinta Wahyu Hati \\ Prodi Administrasi Bisnis Terapan Politeknik Negeri Batam,yovansawir@gmail.com \\ Prodi Administrasi Bisnis Terapan Politeknik Negeri Batam, shinta@polibatam.ac.id
}

\begin{abstract}
This study aims to measure the level of customer satisfaction with the quality of their online service (Wakjek) in Batam city. Primary data obtained by spreading the questionnaires to consumers using Random Sampling techniques with the total sample as many as 100 respondents. The data were analyzed using descriptive statistics. Consumer satisfaction against the dimensions of quality are described on the diagram of the Importance-Performance Analysis (IPA). IPA charts indicate that service dimension items scattered on the four quadrants, namely 15 items on A quadrant which is a top priority, 7 items in quadrant B that should be preserved, the next 7 items in quadrant $C$ which is a low priority, as well as 12 items in quadrant $D$ is an item that is considered less important. Research results exposed that the satisfaction of services provided by taxi online Wakjek has showed the good results it can be seen from the level of conformity that is indicated by the variable $Y$ i.e. satisfaction service. On the attributes of the performance of the average value of the variable $Y$ indicates the number of attributes exist while 4.77 hopes the average value of the variable $Y$ shows numbers 3.62. This means that service satisfaction felt by customers of their online Wakjek have been able to meet the expectations of their customers online Wakjek itself but there are still some items that must be repaired.
\end{abstract}

Keywords: Customer Satisfaction Analysis, Quality of Service, Ojek Online

\begin{abstract}
Abstrak
Penelitian ini bertujuan untuk mengukur tingkat kepuasan konsumen pelanggan terhadap kualitas layanan ojek online (Wakjek) di Kota Batam. Data primer didapatkan dengan menyebarkan kuesioner kepada konsumen menggunakan teknik Random Sampling dengan jumlah sampel sebanyak 100 responden. Data dianalisis dengan menggunakan statistik deskriptif. Kepuasan konsumen terhadap dimensi kualitas digambarkan pada diagram Importance - Performance Analysis (IPA). Diagram IPA menunjukkan bahwa item-item dimensi layanan tersebar pada empat kuadran, yaitu 15 item pada kuadran A yang merupakan prioritas utama, 7 item pada kuadran B yang harus dipertahankan, selanjutnya 7 item di kuadran C yang merupakan prioritas rendah, serta 12 item di kuadran D merupakan item yang dirasa kurang penting. Hasil penelitian memaparkan bahwa kepuasan pelayanan yang diberikan oleh ojek online Wakjek telah menunjukan hasil yang baik hal ini dapat dilihat dari tingkat kesesuaian yang ditunjukan oleh variabel Y yakni kepuasan pelayanan. Pada atribut kinerja nilai rata-rata variabel $\mathrm{Y}$ menunjukan angka 4,77 sedangkan ada atribut harapan nilai rata-rata variabel $\mathrm{Y}$ menunjukan angka 3,62. Hal ini berarti kepuasan pelayanan yang dirasakan oleh pelanggan ojek online Wakjek telah dapat memenuhi harapan dari pelanggan ojek online Wakjek itu sendiri namun masih ada beberapa item yang harus diperbaiki.
\end{abstract}

Kata Kunci: Analisis Kepuasan Pelanggan, Kualitas Layanan, Wakjek 


\section{PENDAHULUAN}

\subsection{Latar Belakang}

Salah satu sektor jasa yang memiliki peranan yang cukup vital dalam menunjang kegiatan sehari-hari adalah sektor jasa transportasi darat. Karena jasa transportasi darat digunakan masyarakat untuk memperlancar aktifitas sehari-hari. Pentingnya transportasi tersebut tercermin pada semakin meningkatnya kebutuhan akan jasa transportasi tersebut, serta dengan meningkatnya jumlah penduduk dan pengembangan pemukiman maupun tempat-tempat hiburan lainnya di kota-kota besar salah satunya di Kota Batam.

Keberadaan jasa transportasi darat ini dirasa sangat penting sekali, khususnya jasa trasportasi yang murah, nyaman, dan aman yang diinginkan oleh masyarakat saat ini. Salah satu bisnis yang sedang berkembang saat ini adalah bisnis jasa transportasi dengan sepeda motor atau yang dulu biasa disebut dengan ojek. Sekarang jasa transportasi ini dikenal dengan istilah baru yaitu ojek online, jika dahulu ojek dikelola secara konvensional dan kepemilikan tunggal, sekarang muncul bisnis baru ojek online yaitu suatu usaha komersial, yang menyediakan jasa transportasi bagi umum dan dikelola secara profesional.

Maraknya bisnis online ini terjadi karena kemajuan zaman dan teknologi, maka muncul lah suatu inovasi yaitu transportasi online yaitu ojek online. di Indonesia sendiri ojek online sudah menjadi perbincangan di kalangan masyarakat dengan Go-jek sebagai pelopor pertama bisnis transportasi online ini yang didirikan pada tahun 2010 oleh Nadiem Makarim, bahkan Go-jek ini telah merambah keseluruh wilayah di Indonesia.

Karena semakin pesatnya pertumbuhan ojek online ini, di Kota Batam sendiri tidak mau ketingalan dengan ojek yang berbasis menggunakan teknologi online ini, maka peluang untuk membuat inovasi ojek online dengan mengagas Wakjek yang didirikan oleh Bapak Burhanudin Nur dengan dipelopori CV. Wakjek Indonesia.

Wakjek merupakan penyedia layanan ojek online pertama di Batam. Sejak tanggal 18 Juli 2016 Wakjek bermitra dengan puluhan pengendara ojek lokal guna menyediakan layanan ojek online terpercaya dengan tarif terjangkau. Hingga saat ini Wakjek telah memiliki jumlah Driver sekitar 200 orang dan User yang telah mengunduh aplikasi ini berjumlah 47.768 orang. Wakjek juga menyediakan beragam layanan yang akan membantu keseharian masyarakat Kota Batam seperti jasa transportasi pengiriman barang hingga pesan antar makanan. Mengunakan aplikasi android yang di buat Wakjek, memudahkan masyarakat dapat melakukan pemesanan layanan ojek online langsung dari smartphone android. Layaknya virus yang menjamur begitu cepat, dan ramai dibicarkan Wakjek sebagai perusahaan lokal yang berkembang sangat pesat di Kota Batam dan menjelma sebagai perusahaan jasa transportasi online pertama yang menawarkan jasa transportasi antar penumpang dengan sepeda motor alias ojek online.

Bila dilihat dari persaingan ojek online yang ada pada saat ini membuat para perusahaan terus meningkatkan kualitas layanan yang mereka berikan kepada pelanggannya. Seperti Go-jek yang kini hadir untuk melayani Kota Batam, mereka memberikan layanan yang sudah tersedia saat ini meliputi GO-RIDE, GO-FOOD, GO-SEND dan $G O-S H O P$ dan dengan namanya yang telah terkenal di seluruh Indonesia. Akan tetapi Wakjek yang merupakan ojek online pertama di Batam tidak mau kalah, meraka juga mengeluarkan fitur-fitur dari aplikasi nya dengan layanan yang tersedia seperti WakFood, Wak-Rent, Wak-Shop. Wakjek juga memiliki kelebihan dari segi aplikasi dengan pemesanan Wakjek secara online para pelanggan bisa langsung melihat dan memilih driver sesuai keinginan meliputi tentang merek motor, jenis kelamin, maupun foto profil dari driver Wakjek tersebut. Selain itu Wakjek juga merupakan ojek online pertama di Kota Batam. Maka dari itu untuk terus meningkatkan kepuasan pelanggan maka para pihak ojek online ini terus berlomba untuk memenuhi dan memperbaiki kualitas layanan dari jasa transportsi tersebut, agar terciptanya kepuasan pelanggan dan memiliki konsumen yang loyal.

Jadi dapat disimpulkan bahwa untuk mengetahui tingkat kepuasan konsumen dapat dilakukan dengan membandingkan antara kinerja /pelayanan yang diberikan perusahaan dan harapan dari konsumen tersebut. Konsumen akan merasa tidak puas apabila kinerja/pelayanan yang diberikan oleh perusahaan tidak sama atau tidak sesuai yang diharapkannya dan sebaliknya konsumen akan merasa puas apabila kinerja/pelayanan yang diberikan perusahaan sama atau sesuai dengan yang diharapkannya. Dengan mengetahui 
Yovan \& Shinta, Analisis Kepuasan Pelanggan...

tingkat kepuasan konsumen tersebut perusahaan dapat memperbaiki kualitas pelayanan yang diberikan kepada konsumen, karena konsumen yang dapat menilai baik atau tidaknya kualitas pelayanan.

Sebuah kualitas layanan dapat diukur dengan menggunakan teori menurut Parasuraman dalam Farida Jasfar (2009:51) yang mengemukakan lima dimensi, yaitu Reliability (Keandalan), Responsiveness (Dayatanggap), Assurance (Jaminan), Empathy (Empati), dan Tangible (Produk-produk fisik). Teori yang dikemukakan adalah untuk menilai dan mengukur kualitas layanan pada perusahaan. Apakah kualitas layanan yang telah diberikan oleh transportasi ojek online Wakjek sangat mempengaruhi keputusan pembelian pada penggunaan jasa Wakjek tersebut. Terkait dengan kualitas layanan, penulis menemukan pengguna jasa layanan transportasi ojek online Wakjek yang menggemukakan masih perlu ada nya perbaikan layanan yang diberikan. Saat ini kenyataannya dilapangan jasa transportasi ojek online Wakjek masih mendapatkan beberapa komplain terkait dengan kinerja maupun harapan oleh pengguna jasa Wakjek, mulai dari komunikasi yang kurang tanggap dari pihak Wakjek nya, maupun pelayanan yang kurang memuaskan dari pihak Wakjek kepada konsumen.

Berdasarkan latar belakang yang terjadi di atas, penulis tertarik untuk membahas masalah kualitas pelayanan yang akan diberikan pihak Wakjek kepada konsumen, dengan mengambil judul penelitian "Analisis kepuasan pelanggan terhadap kualitas layanan ojek online (Wakjek) di Kota Batam”.

\subsection{Rumusan Masalah}

Berdasarkan latar belakang di atas, maka penulis merumuskan masalah tentang sejauh mana tingkat kepuasan pelanggan terhadap ojek online Wakjek di Kota Batam.

\subsection{Tujuan Penelitian}

Adapun tujuan dari penelitian ini adalah untuk mengetahui dan menganalisis kepuasan pelanggan terhadap kualitas layanan ojek online Wakjek di Kota Batam.

\subsection{Manfaat Penelitian}

Adapun manfaat dari penelitian ini adalah:

1. Manfaat Praktis
Sebagai masukan dan saran kepada perusahaan Wakjek agar lebih memperhatikan pelayanan agar menciptakan kepuasan pelanggan serta dapat memperbaiki kualitas dan layanan dari Wakjek.

2. Manfaat Teoritis

a. Sebagai bahan referensi bagi pembaca untuk penelitian selanjutnya dalam perusahaan jasa bagi peneliti yang berminat dalam meneliti transportasi online, dan juga sebagai tambahan untuk menambah wawasan.

b. Sebagai referensi untuk penelitian selanjutnya yang sejenis.

\section{KAJIAN PUSTAKA}

Pemasaran Jasa Menurut Danang Sunyoto, dan Fathonah Eka Susanti (2015:59) mengatakan bahwa pemasaran merupakan suatu proses mempersepsikan, memahami, menstimulasi dan memenuhi kebutuhan pasar sasaran yang dipilih secara khusus dengan menyalurkan sumber-sumber sebuah organisasi untuk memenuhi kebutuhankebutuhan tersebut. Pemasaran jasa mesti menyesuaikan diri dengan selera konsumen, dipengaruhi jumlah pendapatan, tidak ada fungsi penyimpanan, dan kualitas dipengaruhi barang. Yang penting dalam pemasaran jasa tidak lain keandalan, daya tanggap, kepastian, empati, dan berwujud.

Bauran pemasaran jasa merupakan pengembangan bauran pemasaran. Bauran pemasaran (Marketing mix) produk hanya mencakup 4P, yaitu: Product, Price, Place, dan Promotion. Sedangkan untuk jasa keempat $\mathrm{P}$ tersebut masih kurang mencukupi, sehingga para ahli pemasaran menambahkan 3 unsur, yaitu: People, Process, dan Customer Service.

Kualitas Layanan Kualitas layanan suatu perusahaan haruslah terus dipertahankan dan ditingkatkan karena pelanggan mengharapkan mendapat suatu pelayanan yang baik bahkan melebihi yang mereka harapkan sehingga pelanggan akan puas terhadap perusahaan jasa tersebut. Definisi kualitas sendiri menurut Kotler dan Keller (2009:169) adalah "Quality is the totality of features and characteristics of a product or service that bear on its ability to satisfy stated or implied needs". Dari penjelasan di atas bisa disimpulkan bahwa kualitas adalah keseluruhan dari fitur dan 
karakteristik dari sebuah produk atau jasa yang memiliki kemampuan untuk memuaskan kebutuhan.

Sebuah kualitas pelayan tersebut dapat diukur dengan menggunakan teori menurut Parasuraman dalam Jasfar (2009:51) mengemukakan lima dimensi, yaitu Reliability (Keandalan), Responsiveness (Daya tanggap), Assurance (Jaminan), Empathy (Empati), dan Tangible (Produk-produk fisik). Kualitas memiliki hubungan yang sangat erat dengan kepuasan pelanggan, yaitu kualitas memberikan suatu dorongan kepada pelanggan untuk menjalani ikatan hubungan yang kuat dengan perusahaan. Dalam jangka panjang ikatan seperti ini memungkinkan perusahaan untuk memahami dengan seksama harapan pelanggan serta kebutuhan mereka. Dengan demikian, perusahaan dapat meningkatkan kepuasan pelanggan, yang pada gilirannya kepuasan tersebut dapat menciptakan kesetiaan atau loyalitas kepada perusahaan yang memberikan kualitas memuaskan. Agar pelayanan yang diberikan dapat berkualitas baik dan dapat memberikan kepuasan pada konsumennya maka sebaiknya perusahaan perlu memperhatikan berbagai dimensi yang bisa menciptakan dan meningkatkan kualitas pelayanan jasa. Dimensi kualitas jasa Menurut Umar dalam Dwiwinarshi (2009:4) menyatakan ada 5 dimensi kualitas layanan yang meliputi sebagai berikut:

1. Reliability, yaitu kemampuan untuk melaksanakan jasa yang dijanjikan dengan tepat dan terpercaya.

2. Responsiveness, yaitu respon atau kesiapan karyawan dalam membantu pelanggan dan memberikan pelayanan dengan cepat dan tanggap, yang meliputi kesigapan karyawan dalam melayani pelanggan, kecepatan karyawan dalam melayani transaksi, dan penanganan keluhan pelanggan.

3. Assurance, yaitu meliputi kemampuan karyawan atas pengetahuan terhadap produk secara tepat, kualitas keramah tamahan, perhatian dan kesopanan dalam memberikan pelayanan, keterampilan dalam memberikan informasi. Dimensi ini merupakan gabungan dari sub dimensi:
a. Kompetensi
(Competence), keterampilan dan pengetahuan yang dimiliki oleh para karyawan untuk melakukan pelayanan.

b. Kesopanan (Courtesy), meliputi keramahan, perhatian dan sikap para karyawan.

c. Kredibilitas (Credibility), meliputi halhal yang mendukung dengan kepercayaan kepada perusahaan, seperti reputasi, prestasi.

4. Emphaty, yaitu perhatian secara individual yang diberikan perusahaan kepada pelanggan, seperti kemudahan untuk menghubungi perusahaan, kemampuan karyawan untuk berkomunikasi dengan pelanggan, dan usaha perusahaan untuk memahami kebutuhan dan keinginan pelanggannya.

5. Tangible, yaitu segala bukti fisik seperti pegawai, fasilitas, peralatan, tampilan fisik dari pelayanan seperti kendaraan operasional barang dan jasa yang ditawarkan.

Kepuasan Pelanggan Definisi kepuasan pelanggan menurut Zeithaml, Bitner dan Dwayne (2009:104) adalah, "Customer's evaluation of a product or service in terms of whether that product or service has met the customer's needs and expectations". Dimana menurutnya kepuasan pelanggan adalah penilaian pelanggan atas produk ataupun jasa dalam hal menilai apakah produk atau jasa tersebut telah memenuhi kebutuhan dan ekspektasi pelanggan.

Sedangkan definisi lain menurut Kotler dan Keller (2009:164), "Satisfaction is a person's feelings of pleasure or disappointment that result from comparing a product's perceived performance (or outcome) to their expectations". Sehingga menurutnya kepuasan didefinisikan sebagai perasaan pelanggan yang puas atau kecewa yang dihasilkan dari membandingkan kinerja yang dipersepsikan produk (atau hasil) dengan ekspektasi pelanggan.

Jadi penulis menyimpulkan bahwa kepuasan itu adalah perbandingan antara kinerja yang dirasakan dengan harapan. Apabila kinerja dibawah harapan maka pelanggan atau konsumen akan kecewa dan bila kinerja sesuai dengan harapan maka pelanggan atau konsumen akan puas dan bila kinerja melebihi harapan maka pelanggan atau konsumen merasa sangat puas. 
Yovan \& Shinta, Analisis Kepuasan Pelanggan...

\section{METODE}

\section{Rancangan Penelitian}

Jenis penelitian yang digunakan adalah explanatory research. Menurut Sugiyono (2006) penelitian explanatory adalah penelitian yang bermaksud menjelaskan kedudukan variabel-variabel yang diteliti serta hubungan antara satu variabel dengan variabel lainnya. Penelitian ini bermaksud menjelaskan pengaruh antara variabel independen yaitu kepuasan pelanggan terhadap variabel dependen yaitu kualitas layanan.

Pendekatan penelitian yang dilakukan ini melalui beberapa tahap, yakni diawali dengan mengumpulkan data melalui penyebaran kuesioner kepada sejumlah responden yang menjadi sampel penelitian, menentukan instrument penelitian, menentukan metode yang dipergunakan, serta menganalisis data yang sudah terkumpul kemudian disajikan dalam bentuk proposal.

\section{Populasi dan sampel}

Menurut Sugiyono (2008), populasi adalah wilayah generalisasi yang terdiri atas objek atau subjek yang mempunyai kualitas dan karakteristik tertentu yang diterapkan oleh peneliti untuk dipelajari. Dalam penelitian ini yang menjadi populasi adalah masyarakat yang pernah menaiki jasa transportasi ojek online Wakjek di Kota Batam.

Menurut Sugiyono (2008), sampel adalah sebagian dari jumlah dan karakteristik yang dimiliki oleh populasi tersebut. Penentuan pengambilan sampel ditentukan dengan menggunakan teknik purposive sampling. Menurut Arikunto (2006), purposive sampling didasarkan atas ciri-ciri, sifat-sifat atau karakteristik tertentu.

Adapun karakteristik sampelnya adalah:

a. Masyarakat kota Batam

b. Masyarakat yang telah menaiki jasa transportasi ojek online Wakjek

c. Konsumen yang telah menaiki jasa transportasi ojek online Wakjek lebih dari 1 kali

Jumlah populasi yang menggunakan jasa transportasi ojek online Wakjek di Kota Batam tidak diketahui, maka pengambilan sampel menggunakan rumus sebagai berikut:

$$
n i=\frac{\mathrm{T}-\mathrm{to}}{t i}
$$

Keterangan:

$\mathrm{T} \quad$ : Jumlah waktu to : Jumlah waktu yang direncanakan

ti : Waktu yang dibutuhkan untuk mengisi kuesioner

i $\quad$ : Hari $=5$ jam waktu yang tersedia

$$
\begin{gathered}
n=\frac{14 \text { hari }-4 \text { hari }}{30 \text { menit }} \\
n=\frac{4200-1200}{30 \text { menit }} \\
n=100
\end{gathered}
$$

Jadi sampel dalam penelitian ini sebanyak 100 responden (Menurut Sudarmayanti dalam Hati dkk (2014)).

\section{Kerangka Pemikiran}

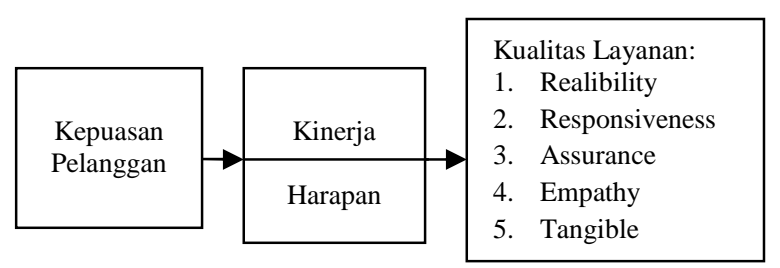

Gambar: 2.1 Kerangka Penelitian

Sumber : Data Olahan Peneliti (2017)

\section{Validitas}

Validitas adalah suatu ukurann yang menunjukkan tingkat kevalidan atau kesahihan suatu instrument. Uji validitas digunakan untuk mengukur sah atau valid tidaknya suatu kuesioner. Suatu kuesioner dikatakan valid jika pertanyaan pada kuesioner mampu untuk mengungkapkan sesuatu yang akan diukur oleh kuesioner tersebut. Uji signifikansi dilakukan dengan cara membandingkan nilai $r$ hitung dengan $r$ tabel untuk degree of freedom $(\mathrm{df})=$ n-2.

\section{Reliabilitas}

Reliabilitas adalah alat untuk mengukur suatu kuesioner yang merupakan indikator dari variabel atau konstruk. Suatu kuesioner dikatakan reliabel atau handal jika jawaban seseorang terhadap pernyataan adalah konsisten atau stabil dari waktu ke waktu. Kuesioner dikatakan reliabel apabila hasil uji statistik alpha $\alpha \geq 0.60$ (Sugiyono,2008).

\section{Statistik Deskriptif}

Statistik deskriptif adalah statistik yang digunakan untuk menganalisis data dengan cara mendeskripsikan atau menggambarkan 
data yang telah terkumpul sebagaimana adanya tanpa bermaksud membuat kesimpulan yang berlaku untuk umum atau generalisasi (Sugiyono,2015).

\section{Importance Performance Analysis (IPA) Analisis Tingkat Kesesuaian.}

Merupakan suatu teknik yang digunakan untuk mengukur tingkat kepentingan dan tingkat kenerja atribut. Data yang akan diolah dalam penelitian ini berasal dari kuesioner dan guna menjawab semua pertanyaan dalam kuesioner.

Importance-Performance Analysis (IPA), merupakan alat bantu dalam menganalisis atau yang digunakan untuk membandingkan sampai sejauh mana antara kinerja/pelayanan yang dapat dirasakan oleh pengguna jasa dibandingkan terhadap tingkat kepuasan yang diinginkan. Tingkat kesesuaian merupakan hasil perbandingan antara skor kinerja pelaksanaan dengan skor kepentingan, sehingga tingkat kesesuaian inilah yang akan menentukan skala perioritas yang akan dipakai dalam penanganan.

\section{PEMBAHASAN}

\section{Profil Perusahaan}

Wakjek adalah penyedia layanan ojek online pertama di Batam. Wakjek bermitra dengan puluhan pengendara ojek lokal guna menyediakan layanan ojek online terpercaya dengan tarif terjangkau. Wakjek menyediakan beragam layanan yang akan membantu keseharian seperti jasa transportasi, pengiriman barang hingga pesan antar makanan.

Wakjek yang beralamat di Ruko Anggrek Mas 2 Blok A2 No 16 Batam Center itu mulai beroperasi di Batam sejak 18 Juli 2016 lalu. Sejak itu, bisnis yang berprinsip tumbuh bersama para driver nya itu, makin dikenal masyarakat Batam.

Wakjek sendiri memiliki aplikasi terbaru, dalam aplikasi itu pengguna Wakjek bisa memilih sopir perempuan dan laki-laki bisa, dan kendaraan sesuai dengan kebutuhan pengguna Wakjek soalnya jenis motor akan di jelaskan dalam aplikasi tersebut, demi kenyamanan user Wakjek.

Wakjek sendiri berasal dari bahasa Melayu. Wak, selalu digunakan dalam percakapan atau panggilan kedekatan dengan teman akrab dan saudara. Tujuannya, pemilihan nama Wakjek itu diharapkan setiap pengguna jasa Wakjek merasa lebih dekat dan nyaman dengan fasilitas yang diberikan.

Wakjek sekarang ini tidak hanya menyajikan jasa transportasi ojek saja, Tetapi juga taksi, jasa mengantar pesanan makanan, service AC dan rental mobil. Semuanya ditampilkan dalam aplikasi dan user Wakjek tinggal meng-klik dan melanjutkan sesuai dengan keinginan user masing-masing. Bekerja sama dengan perusahaan rental mobil, jika ada user yang membutuhkan mobil, dan AC juga begitu, kita mendapatkan fee dari perusahaan tersebut.

Untuk Wakjek yang menggunakan jaket berwarna orange ini, dalam menggunaan kendaraan 4 Kilometer pertama sudah ditarif denga biaya Rp 10 ribu, untuk tambahan kilo meter selanjutnya akan ditambah $\mathrm{Rp} 2$ ribu setiap penambahan 1 kilo meter. Sedangkan pengiriman barang atau makanan Wakjek menghitung 3 Kilometer akan dihargai Rp 15 ribu.

WakJek menggunakan aplikasi android untuk memudahkan anda dalam menggunakan layanan ojek online Wakjek. Dengan aplikasi android Wakjek, anda dapat melakukan pemesanan layanan ojek online langsung dari smartphone android dengan sangat mudah.

\section{Karakteristik Responden}

Pada penelitian ini metode utama pengumpulan data adalah dengan menggunakan kuisioner yang berjumlah 100 kuisioner disebarkan kepada responden yaitu para konsumen Wakjek di Kota Batam. Berdasarkan hasil penyebaran kuisioner, semua kuisioner dapat tersebar dan terisi. Adapun rekapitulasi jumlah kuisioner yang tersebar dan terisi adalah sebagai berikut:

Tabel 1 Rekapitulasi Jumlah Kuisioner

\begin{tabular}{|c|c|c|c|}
\hline \multirow{2}{*}{$\begin{array}{c}\text { Jumlah } \\
\text { Responden }\end{array}$} & Tersebar & Terisi & Dapat Diolah \\
\cline { 2 - 4 } & 100 & 100 & 100 \\
\hline
\end{tabular}

Sumber: Data Olahan Peneliti, 2017

Berdasarkan data pada tabel diketahui dilakukan telah sesuai dengan target yang bahwa hasil penyebaran kuisioner yang diharapkan untuk memenuhi data kebutuhan 
Yovan \& Shinta, Analisis Kepuasan Pelanggan...

"Analisis Kepuasan Pelanggan Terhadap Kualitas Layanan Ojek Online (Wakjek) Di Kota Batam".

\section{Karakteristik Responden}

Karakteristik Responden merupakan identitas responden yang memberikan respon terhadap obyektivitas dari penelitian "Analisis Kepuasan Pelanggan Terhadap Kualitas Layanan Ojek Online (Wakjek) Di Kota Batam”. Responden dalam penelitian ini adalah para konsumen dari ojek online Wakjek Kota Batam dengan jumlah 100 responden.

Karakteristik responden berguna dalam penguraian deskripsi identitas responden menurut sampel penelitian yang telah

Tabel 2 Karakteristik Responden Berdasarkan Jenis Kelamin

\begin{tabular}{|c|c|c|c|}
\hline No & Jenis Kelamin & Frekuensi & Persentase (\%) \\
\hline 1 & Laki-laki & 48 & $48 \%$ \\
\hline 2 & Perempuan & 52 & $52 \%$ \\
\hline \multicolumn{2}{|r|}{ Total } & 100 & $100 \%$ \\
\hline
\end{tabular}

Sumber: Data Olahan Peneliti, 2017

Berdasarkan data pada tabel diatas, dapat diketahui bahwa jumlah responden lakilaki sebanyak 48 orang atau $48 \%$ dan jumlah responden perempuan sebanyak 52 orang atau $52 \%$.

Untuk responden perempuan lebih banyak daripada responden laki laki dikarenakan jumlah penduduk Di Kota batam lebih banyak perempuan daripada laki-laki, dan jumlah pekerja pun lebih banyak ditetapkan. Salah satu tujuan karakteristik responden adalah memberikan gambaran yang menjadi sampel dalam penelitian.

\section{a. Karakteristik Responden Berdasarkan Jenis kelamin}

Untuk mempermudah proses analisa, karakteristik responden berdasarkan jenis kelamin dibedakan menjadi dua yaitu: LakiLaki dan Perempuan, Hasil Analisa karakteristik responden berdasarkan jenis kelamin adalah sebagai berikut:

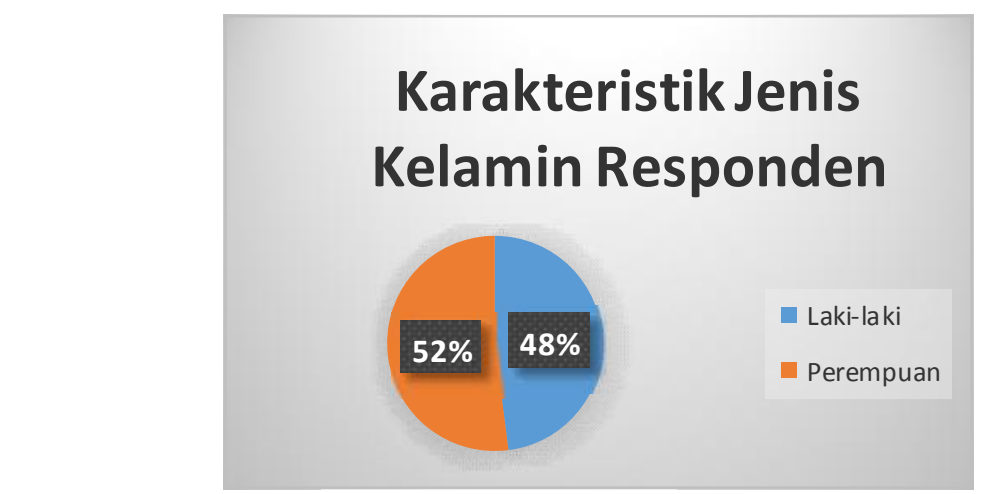

Gambar 1 Diagram Pie Karakteristik Responden Berdasarkan Jenis Kelamin Sumber: Data Olahan Peneliti (2017)

\section{b. Karakteristik Responden Berdasarkan Usia}

Untuk mempermudah proses analisa, saat proses analisa rentang usia responden dipisahkan oleh penulis menjadi 4 kriteria perempuan daripada laki-laki, disini perempuan pengguna jasa ojek online Wakjek ini dapat disimpulkan bahwa mereka banyak yang belum memiliki kendaraan pribadi dan merasa memakai jasa ojek online Wakjek sangat membantu mereka untuk berpergian. Untuk lebih jelas karaktersitik responden berdasarkan jenis kelamin dapat dilihat pada diagram di bawah ini: yakni $<17$ tahun, 17 s/d 26 tahun, 27 s/d 36 tahun, 37 s/d 46 tahun dan 47 s/d 56 tahun keatas. Hasil analisa karakteristik responden berdasarkan kelompok usia adalah sabagai berikut: 
Journal of Applied Business Administration Vol 1, No 1, Maret 2017, hlm. 96-121

Tabel 3 Karakteristik Responden Berdasarkan Usia

\begin{tabular}{|c|c|c|c|}
\hline No & Rentang Usia & Jumlah & Persentase \\
\hline 1 & $<17$ Tahun & 10 & $10 \%$ \\
\hline 2 & 17 s/d 26 Tahun & 35 & $35 \%$ \\
\hline 3 & 27 s/d 36 Tahun & 25 & $25 \%$ \\
\hline 4 & 37 s/d 46 Tahun & 20 & $20 \%$ \\
\hline 5. & 47 s/d 56 Tahun & 10 & $10 \%$ \\
\hline \multicolumn{2}{|r|}{ Total } & 100 & $100 \%$ \\
\hline
\end{tabular}

Sumber: Data Olahan Peneliti, 2017

Berdasarkan data pada tabel diatas, diketahui bahwa jumlah responden yang memiliki rentang usia $<17$ tahun berjumlah $10 \%$ responden $(10 \%)$, rentang usia $17 \mathrm{~s} / \mathrm{d} 26$ tahun berjumlah 35 responden(35\%), rentang usia $27 \mathrm{~s} / \mathrm{d} 36$ tahun berjumlah 25 responden (25\%), rentang usia $37 \mathrm{~s} / \mathrm{d} 46$ tahun berjumlah 20 responden (20\%) dan yang memiliki rentang usia $47 \mathrm{~s} / \mathrm{d} 56$ tahun berjumlah 10 responden $(10 \%)$.

Pada penelitian ini karakteristik usia responden persentase yang paling besar adalah pada rentang usia 17 s/d 26 tahun pada rentang usia ini merupakan usia remaja menuju ke dewasa, dimana bisa dikatakan usia pengguan Wakjek rata-rata usia Produktif dimana para responden banyak menggunakan jasa ojek online Wakjek untuk melakukan aktivitas sehari-hari seperti kuliah, bekerja, berbelanja maupun yang lain, dan diusia ini pula banyak yang mengikuti tren modern/zaman modern karena transportasi berbasis online sedang marak dibicarakan. Berikut persentase karakteristik responden berdasar rentang usia jika dilihat dari diagram pie:

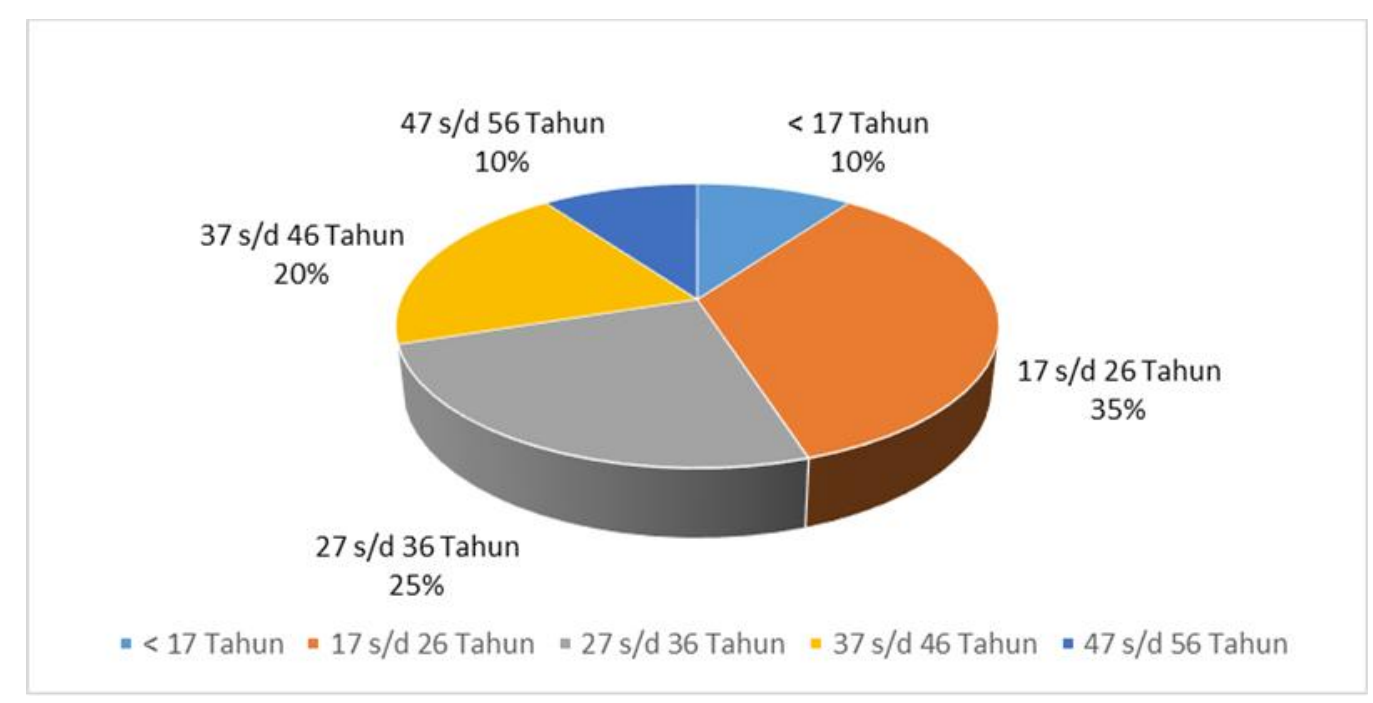

Gambar 2 Diagram Pie Karakteristik Responden Berdasarkan Rentang Usia Sumber: Data Olahan Peneliti (2017)

\section{c. Karakteristik Responden Berdasarkan Pendidikan}

Karakteristik responden berdasarkan Pendidikan dikelompokan menjadi 6 kriteria yaitu: SD/Sederajat, SMP/Sederajat,
SMA/Sederajat, Diploma, Sarjana, Pasca Sarjana. Hasil analisa terhadap karakteristik responden berdasarkan pendidikan adalah sebagai berikut: 
Yovan \& Shinta, Analisis Kepuasan Pelanggan...

Tabel 4 Karakteristik Responden Berdasarkan Pendidikan

\begin{tabular}{|c|c|c|c|}
\hline No & Pendidikan Terakhir & Jumlah & Persentase (\%) \\
\hline 1 & SD/Sederajat & 5 & $5 \%$ \\
\hline 2 & SMP/Sederajat & 10 & $10 \%$ \\
\hline 3 & SMA/Sederajat & 35 & $35 \%$ \\
\hline 4 & Diploma & 30 & $30 \%$ \\
\hline 5 & Sarjana & 20 & $20 \%$ \\
\hline 6 & Pasca Sarjana & - & - \\
\hline \multicolumn{2}{|c|}{ Total } & 100 & $100 \%$ \\
\hline
\end{tabular}

Sumber: Data Olahan Peneliti, 2017

Berdasarkan tabel karakteristik responden berdasarkan pendidikan diatas, dapat diketahui rentang pendidikan responden dimulai dari yang tamatan SD/Sederajat berjumlah 5 responden $(5 \%)$, SMP/Sederajat 10 responden (10\%), SMA/Sederajat 35 Responden (35\%), Diploma 30 responden (30\%), Sarjana 20 responden (20\%), dan Pasca Sarjana Tidak ada Responden.

Berdasarkan karakteristik dalam pendidikan dapat disimpulkan bahwa responden paling banyak menggunakan Wakjek ini adalah responden berpendidikan terakhir SMA/Sederajat dengan jumlah responden 35 orang dengan persentase $35 \%$, dikarenakan banyak yang mengguankan jasa ojek online Wakjek dengan karakteristik pendidikan SMA/Sederajat banyak yang bekerja dan berkuliah, dikarenakan mereka lebih memilih menggunakan jasa Wakjek agar lebih cepat sampai dan tidak capek untuk berkendaraan sendiri. Berikut persentase karakteristik responden berdasarkan rentanng Pendidikan jika dilihat dari diagram pie:

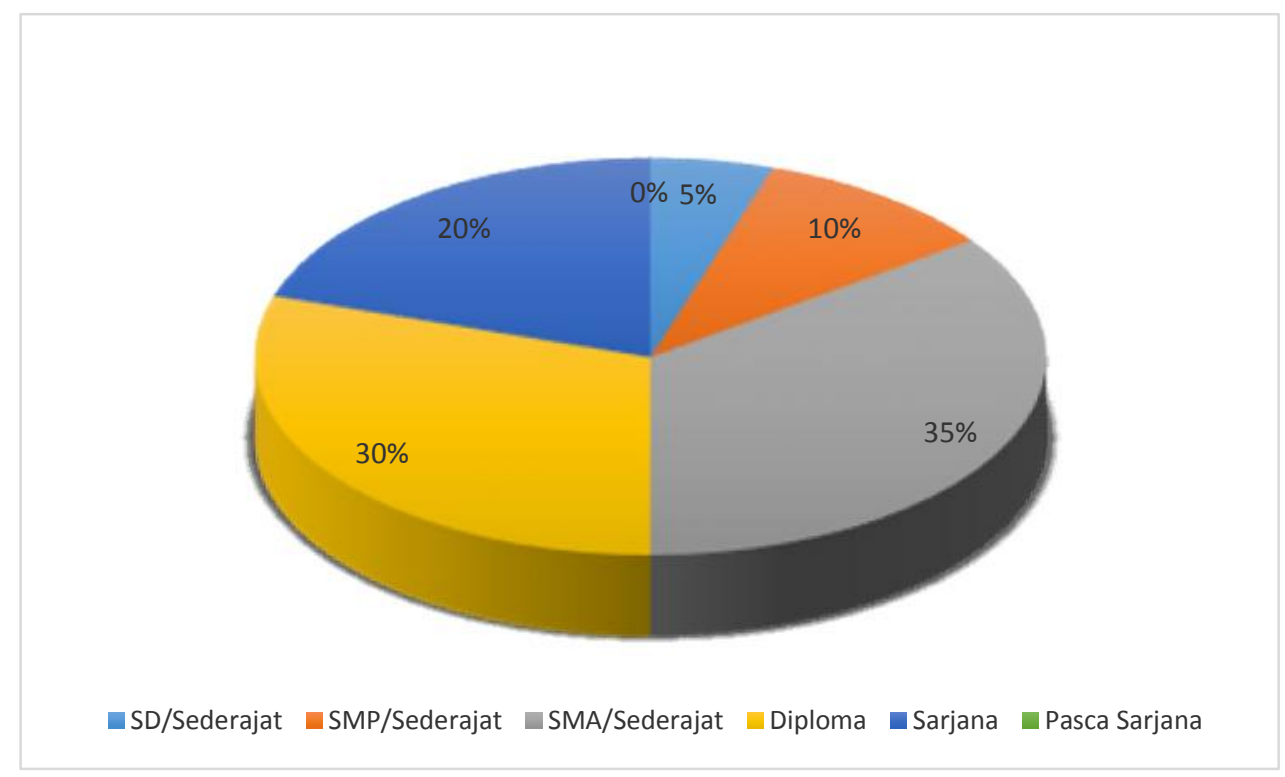

Gambar 3 Diagram Pie Karakteristik Responden Berdasarkan Pendidikan Sumber: Data Olahan Peneliti (2017)

\section{d. Karakteristik Responden Berdasarkan Profesi}

Karakteristik responden berdasarkan profesi dibagi menjadi 5 bagian profesi yaitu:
Pelajar/Mahasiswa, PNS, Karyawan Swasta, Belum Bekerja, Wirausaha. Hasil analisa terhadap karakteristik responden berdasarkan profesi adalah sebagai berikut : 
Journal of Applied Business Administration Vol 1, No 1, Maret 2017, hlm. 96-121

Tabel 5 Karakteristik Responden Berdasarkan Profesi

\begin{tabular}{|c|c|c|c|}
\hline No & Profesi & Jumlah & Persentase (\%) \\
\hline 1 & Pelajar/Mahasiswa & 30 & $30 \%$ \\
\hline 2 & PNS & 15 & $15 \%$ \\
\hline 3 & Karyawan Swasta & 35 & $35 \%$ \\
\hline 4 & Belum Bekerja & 5 & $5 \%$ \\
\hline 5 & Wirausaha & 15 & $15 \%$ \\
\hline & Total & 100 & $100 \%$ \\
\hline
\end{tabular}

Sumber: Data Olahan Peneliti, 2017

Berdasarkan tabel karakteristik responden berdasarkan profesi dapat disimpulkan bahwa responden paling banyak menggunakan Wakjek ini adalah responden dengan profesi sebagai karyawan swasta dengan 35\% dikuti dengan responden berprofesi sebagai pelajar/mahasiswa dan seterusnya.

Profesi sebagai karyawan swasta banyak menggunakan jasa wakjek dikarenakan Wakjek dapat dihandalkan dalam kondisi apapun karena Wakjek dapat mengantar penumpang maupun mengantar pesanan, selanjutnya untuk pelajar dan mahasiswa banyak yang menggunakan jasa Wakjek dikarenakan sebagian dari mereka tidak memiliki surat izin menggemudi jadi mereka lebih mengandalkan jasa ojek online Wakjek, dan untuk profesi wirausaha banyak yang menggunakan jasa Wakjek untuk mengantar dan menggirim kan barang pesanan dengan ada nya Wakjek terciptalah satu pasok rantai supplychan. Berikut persentase karakteristik responden berdasarkan profesi jika dilihat dari diagram pie:

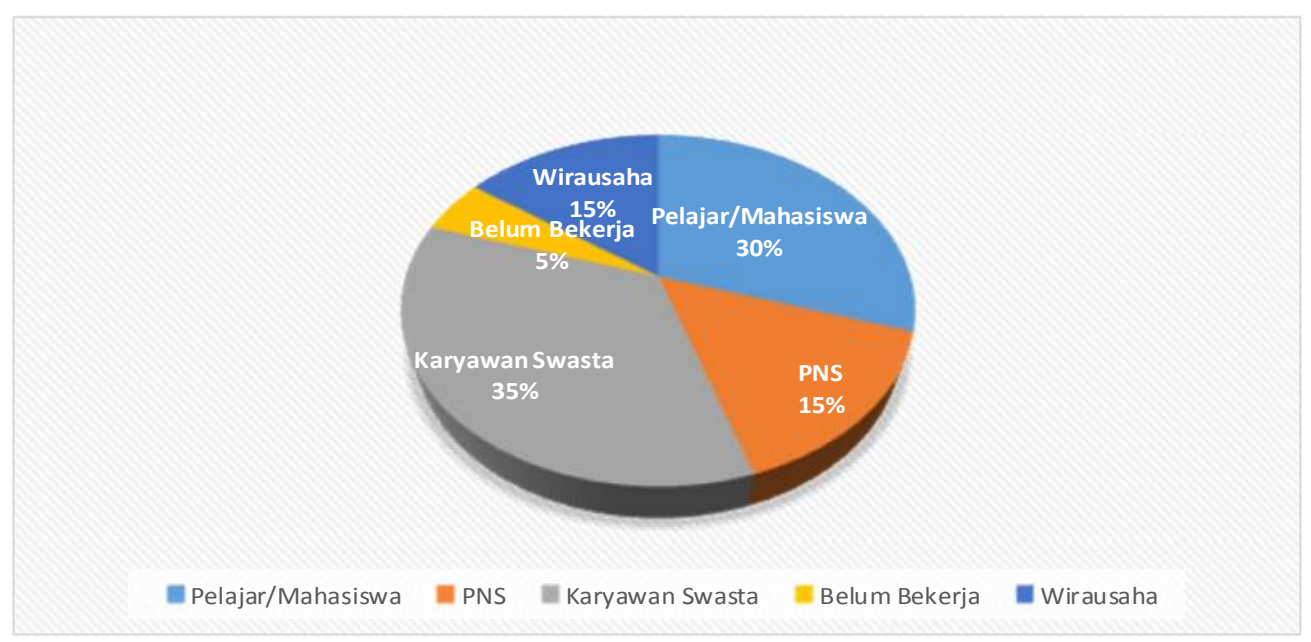

Gambar 4 Diagram Pie Karakteristik Responden Berdasarkan Profesi Sumber: Data Olahan Peneliti (2017)

e. Karakteristik Responden Berdasarkan Seberapa Sering Menggunakan jasa Wakjek dalam 1 Bulan Terakhir

Karakteristik responden berdasarkan seberapa sering menggunakan jasa ojek online
Wakjek dibagi menjadi 4 karakteristis yaitu: 2 kali, 3 kali, 4 - 5 kali, diatas 5 kali. Hasil analisa terhadap karakteristik responden berdasarkan penggunaan jasa Wakjek adalah sebagai berikut :

Tabel 6 Karakteristik Responden Berdasarkan Penggunaan Jasa dalam 1 Bulan terakhir

\begin{tabular}{|c|c|c|c|}
\hline No & Penggunaan jasa Wakjek & Jumlah & Persentase (\%) \\
\hline 1 & $2 \mathrm{Kali}$ & 52 & $52 \%$ \\
\hline 2 & $3 \mathrm{Kali}$ & 23 & $23 \%$ \\
\hline 3 & $4-5 \mathrm{Kali}$ & 20 & $20 \%$ \\
\hline 4 & $>5 \mathrm{Kali}$ & 5 & $5 \%$ \\
\hline \multicolumn{2}{|r|}{ Total } & 100 & $100 \%$ \\
\hline
\end{tabular}

Sumber: Data Olahan Peneliti, 2017 
Yovan \& Shinta, Analisis Kepuasan Pelanggan...

Berdasarkan tabel karakteristik responden berdasarkan penggunaan jasa dalam 1 bulan terakhir maka dapat disimpulkan bahwa responden banyak yang telah menaiki ojek online Wakjek sebanyak 2 kali dengan persentase $52 \%$ responden telah menaiki
Wakjek sebanyak 1 kali dan paling sedikit dengan menaiki ojek online Wakjek sebanyak $>5$ kali dengan persentase 5\%. Berikut persentase karakteristik responden berdasarkan penggunaan jasa dalam 1 bulan terakhir jika dilihat dari diagram pie:

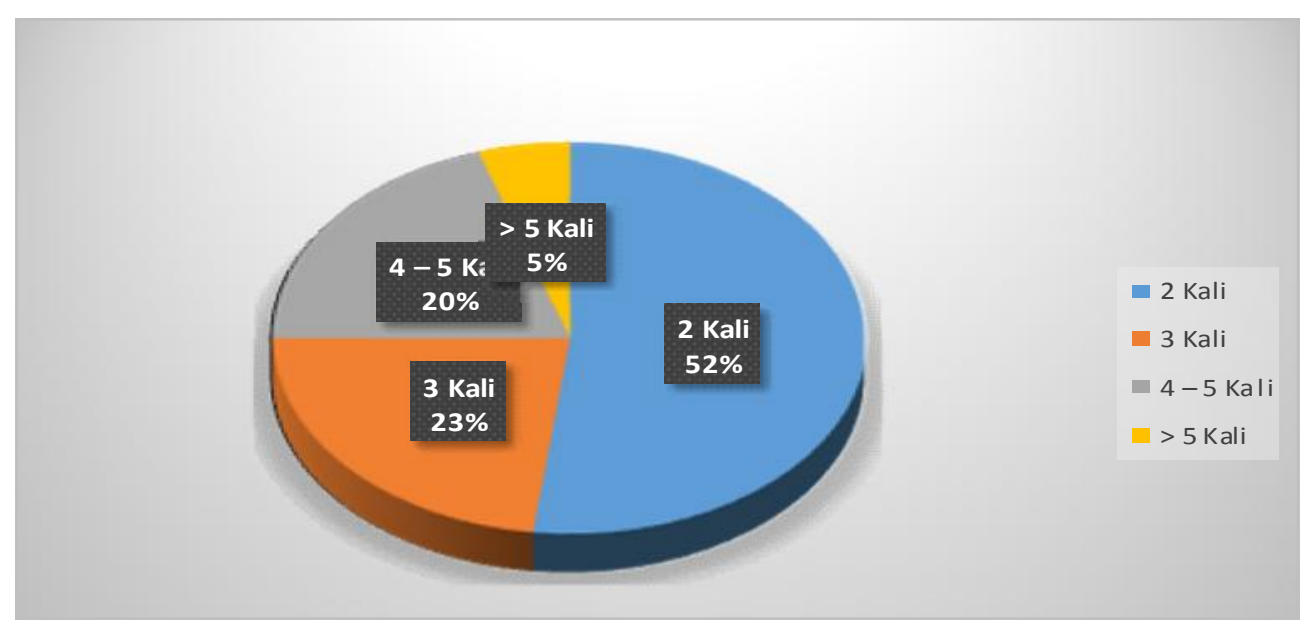

Gambar 5 Diagram Pie Karakteristik Responden Berdasarkan Penggunaan Jasa dalam 1 Bulan Terakhir Sumber: Data Olahan Peneliti (2017)

\section{f. Karakteristik Responden Berdasarkan Memperoleh Informasi}

Karakteristik responden berdasarkan darimana memperoleh informasi mengenai ojek online Wakjek dengan dibagi menjadi 8 bagian yaitu: Keluarga, Teman/Relasi, Brosur, Internet, Koran, Media Sosial, Tv Lokal, Majalah. Hasil analisa terhadap karakteristik responden berdasarkan memperoleh informasi adalah sebagai berikut:

Tabel 7 Karakteristik Responden Berdasarkan Memperoleh Informasi

\begin{tabular}{|c|c|c|c|}
\hline No & Penggunaan jasa Wakjek & Jumlah & Persentase (\%) \\
\hline 1 & Keluarga & 24 & $24 \%$ \\
\hline 2 & Teman/Relasi & 26 & $26 \%$ \\
\hline 3 & Brosur & - & - \\
\hline 4 & Internet & 20 & $20 \%$ \\
\hline 5 & Koran & 10 & $15 \%$ \\
\hline 6 & Media Massa & 10 & $15 \%$ \\
\hline 7 & Tv Lokal & - & - \\
\hline 8 & Majalah & - & $100 \%$ \\
\hline
\end{tabular}

Sumber: Data Olahan Peneliti, 2017

Berdasarkan tabel karakteristik responden berdasarkaan memperoleh informasi banyak responden cenderung mengetahui informasi ojek online Wakjek melalui teman/relasi sebanyak 26\% dikarenakan Wakjek ini sendiri menjadi baahan oerbincangan dimasyarakan dan juga ojek online pertama di Kota Batam. Berikut persentase karakteristik responden berdasarkan perolehan informasi jika dilihat dari diagram pie: 


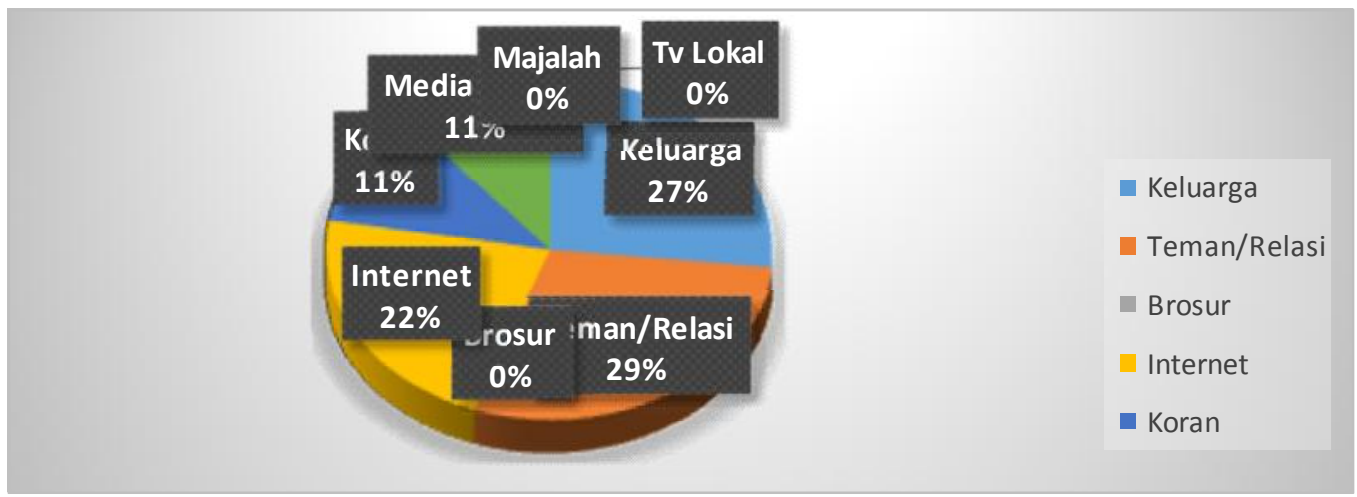

\section{Gambar 6 Diagram Pie Karakteristik Responden Berdasarkan Memperoleh informasi} Sumber: Data Olahan Peneliti (2017)

g. Karakteristik Responden Berdasarkan Pertimbangan Menggunakan Jasa

Karakteristik responden berdasarkan pertimbangan menggunakan jasa ojek online Wakjek dibagi menjadi 4 bagian yaitu: suasana yang nyaman, harga terjangkau, pelayanan dari awal sampe akhir, mudah dipesan. Hasil analisa terhadap karakteristik responden berdasarkan pertimbangan menggunakan jasa ojek online Wakjek adalah sebagai berikut :

Tabel 8 Karakteristik Responden Berdasarkan Pertimbangan Menggunakan Jasa

\begin{tabular}{|c|l|c|c|}
\hline No & \multicolumn{1}{|c|}{ Penggunaan jasa Wakjek } & Jumlah & Persentase (\%) \\
\hline 1 & Suasana yang nyaman & 25 & $25 \%$ \\
\hline 2 & Harga terjangkau & 10 & $10 \%$ \\
\hline 3 & Pelayanan dari awal sampe akhir & 40 & $40 \%$ \\
\hline 4 & Mudah dipesan & 25 & $25 \%$ \\
\hline \multicolumn{2}{r}{ Total } & 100 & $100 \%$ \\
\hline
\end{tabular}

Sumber: Data Olahan Peneliti, 2017

Berdasarkan tabel karakteristik responden berdasarkaan pertimbangan menggunakan jasa responden cenderung memilih pelayanan dari awal sampe akhir dengan persentase $40 \%$, ini dikarenakan ojek online Wakjek memiliki komitment dalam melakukan pelayanan sehingga mereka memberikan pelayanan ke pada pelanggan dari awal pemesanan hingga akhir dari pemesanan dan penggantaran pelanggan tersebut. Berikut persentase karakteristik responden berdasarkan pertimbangan menggunakan jasa ojek online Wakjek jika dilihat dari diagram pie:

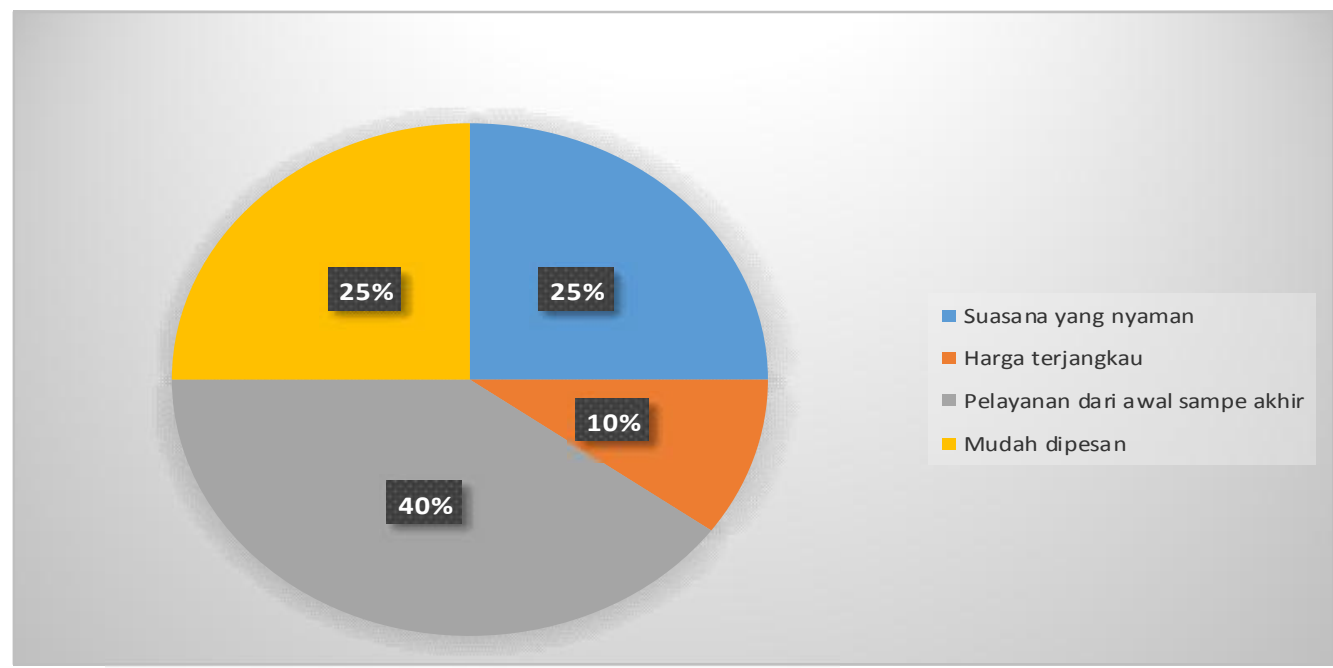

Gambar 7 Diagram Pie Karakteristik Responden Berdasarkan Pertimbangan Menggunakan Jasa Sumber: Data Olahan Peneliti (2017) 
Yovan \& Shinta, Analisis Kepuasan Pelanggan...

\section{h. Karakteristik Responden Berdasarkan Jarak Yang Ditempuh}

Karakteristik responden berdasarkan jarak yang ditempuh ada 6 kriteria yaitu: jarak $<1$
Km, $1-5 \mathrm{Km}, 6-10 \mathrm{Km}, 11-15 \mathrm{Km}, 16-$ $20 \mathrm{Km}$, > $20 \mathrm{Km}$. Hasil analisa terhadap karakteristik responden berdasarkan jarak yang ditempuh adalah sebagai berikut:

Tabel 9 Karakteristik Responden Berdasarkan Jarak Yang Ditempuh

\begin{tabular}{|c|c|c|c|}
\hline No & Jarak Yang Ditempuh & Jumlah & Persentase (\%) \\
\hline 1 & $<1 \mathrm{Km}$ & 25 & $25 \%$ \\
\hline 2 & $1-5 \mathrm{Km}$ & 24 & $24 \%$ \\
\hline 3 & $6-10 \mathrm{Km}$ & 26 & $26 \%$ \\
\hline 4 & $11-15 \mathrm{Km}$ & 25 & $25 \%$ \\
\hline 5 & $16-20 \mathrm{Km}$ & - & - \\
\hline 6 & $>20 \mathrm{Km}$ & - & $100 \%$ \\
\hline
\end{tabular}

Sumber: Data Olahan Peneliti, 2017

Berdasarkan tabel karakteristik responden berdasarkaan jarak yang ditempuh responden banyak yang menggunakan ojek online Wakjek dengan jarak tempuh $6-10$ $\mathrm{Km}$ dengan persentase $26 \%$, bisa dilihat banyak para pelanggan Wakjek yang memilih untuk menggukan jasa wakjek dengan jarak yang lumayan jauh dikarenakan banyak yang menggunakan untuk bekerja maupun memesan barang. Berikut persentase karakteristik responden berdasarkan pertimbangan menggunakan jasa ojek online Wakjek jika dilihat dari diagram pie:

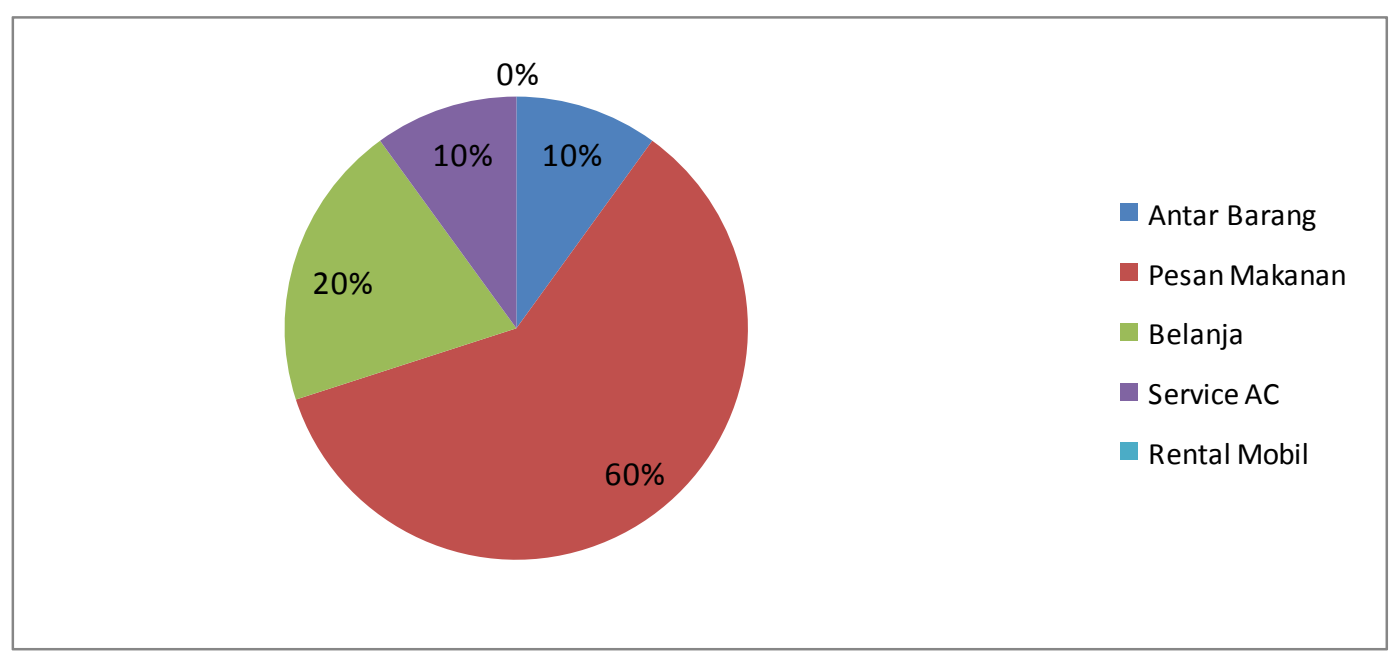

Gambar 8

Diagram Pie Karakteristik Responden Berdasarkan Jarak Yang Ditempuh Sumber: Data Olahan Peneliti (2017)

\section{i. Karakteristik Responden Berdasarkan Keputusan Layanan Yang Dipilih}

Karakteristik responden berdasarkan keputusan layanan yang dipilih di kelompokan menjadi 5 bagian yaitu: Antar Barang, Pesan
Makanan, Belanja, Service AC, Rental Mobil. Hasil analisa terhadap karakteristik responden berdasarkan Layanan yang dipilih adalah sebagai berikut : 
Journal of Applied Business Administration Vol 1, No 1, Maret 2017, hlm. 96-121

Tabel 10 Karakteristik Responden Berdasarkan Layanan Yang Dipiih

\begin{tabular}{|c|c|c|c|}
\hline No & Layanan Yang Dipilih & Jumlah & Persentase (\%) \\
\hline 1 & Antar Barang & 10 & $10 \%$ \\
\hline 2 & Pesan Makanan & 60 & $60 \%$ \\
\hline 3 & Belanja & 20 & $20 \%$ \\
\hline 4 & Service AC & 10 & $10 \%$ \\
\hline 5 & Rental Mobil & - & - \\
\hline & Total & 100 & $100 \%$ \\
\hline
\end{tabular}

Sumber: Data Olahan Peneliti, 2017

Berdasarkan tabel karakteristik responden berdasarkaan keputusan layanan yang dipilih responden banyak yang menggunakan ojek online Wakjek dengan memilih layanan Pemesanaan makanan dengan persentase $60 \%$, karena banyak pelanggan dari Wakjek menggunakan jasa ojek online Wakjek ini untuk melakukan pemesanan makanan karena jasa Wakjek memudahkan kita dalam melakukan pemesanan dan Wakjek pun dapat dihandalkan dalam hal belanja, antar barang maupun service AC. Berikut persentase karakteristik responden berdasarkan keputusan layanana yang dipilih jika dilihat dari diagram pie:

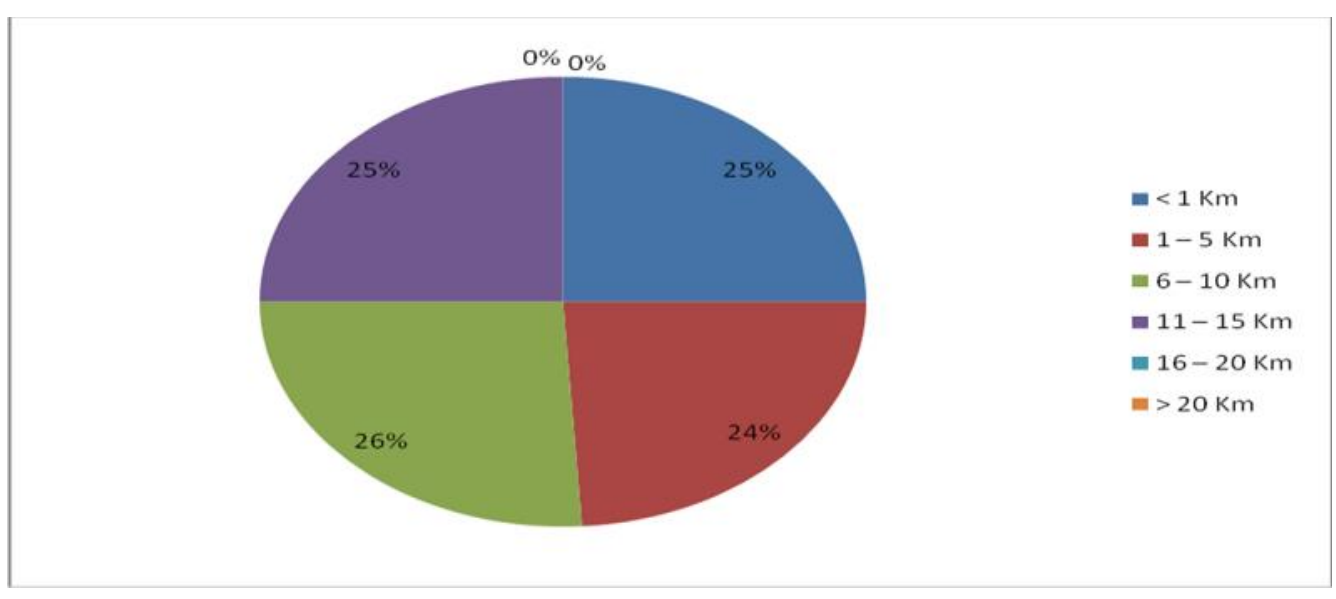

Gambar 9 Diagram Pie Karakteristik Responden Berdasarkan Jarak Yang Ditempuh Sumber: Data Olahan Peneliti (2017)

\section{Deskripsi Variabel Penelitian}

\section{Deskripsi Variabel Reliability (X1)}

Variabel penelitian kemampuan untuk melaksanakan jasa diukur dengan menggunakan 8 item pertanyaan disetiap kinerja maupun harapan responden dari dimensi variabel mengidentifikasi kemampuan untuk melaksanakan jasa. Berdasarkan data yang terkumpul dari 100 responden mengenai kemampuan untuk melaksanakan jasa dari ojek online Wakjek adalah sebagai berikut: 
Yovan \& Shinta, Analisis Kepuasan Pelanggan...

Tabel 1 Variabel Reliability (X1) Kinerja dan Harapan

\begin{tabular}{|c|c|c|c|c|c|c|c|c|c|c|c|c|c|c|c|c|c|c|c|c|c|c|}
\hline \multirow{4}{*}{ Item } & \multicolumn{21}{|c|}{ Skor Jawaban } & \multirow{4}{*}{ Mean } \\
\hline & \multicolumn{10}{|c|}{ Kinerja } & \multirow{3}{*}{ Mean } & \multicolumn{10}{|c|}{ Harapan } & \\
\hline & \multicolumn{2}{|c|}{1} & \multicolumn{2}{|c|}{2} & \multicolumn{2}{|c|}{3} & \multicolumn{2}{|c|}{4} & \multicolumn{2}{|c|}{5} & & \multicolumn{2}{|c|}{1} & \multicolumn{2}{|c|}{2} & \multicolumn{2}{|c|}{3} & \multicolumn{2}{|c|}{4} & \multicolumn{2}{|c|}{5} & \\
\hline & $\mathrm{f}$ & $\%$ & $\mathrm{f}$ & $\%$ & $\mathrm{f}$ & $\%$ & $\mathrm{f}$ & $\%$ & $f$ & $\%$ & & $\mathrm{f}$ & $\%$ & $\mathrm{f}$ & $\%$ & $\mathrm{f}$ & $\%$ & $\mathrm{f}$ & $\%$ & $\mathrm{f}$ & $\%$ & \\
\hline $\mathrm{X} 1.1$ & 0 & 0 & 2 & 2 & 20 & 20 & 56 & 56 & 22 & 22 & 3.98 & 0 & 0 & 10 & 10 & 43 & 43 & 39 & 39 & 8 & 8 & 3.45 \\
\hline $\mathrm{X} 1.2$ & 0 & 0 & 4 & 4 & 20 & 20 & 50 & 50 & 26 & 26 & 3.98 & 0 & 0 & 8 & 8 & 39 & 39 & 46 & 46 & 1 & 7 & 3.52 \\
\hline $\mathrm{X} 1.3$ & 0 & 0 & 0 & 0 & 24 & 24 & 68 & 68 & 8 & 8 & 3.84 & 0 & 0 & 9 & 9 & 42 & 42 & 42 & 42 & 7 & 7 & 3.47 \\
\hline $\mathrm{X} 1.4$ & 0 & 0 & 12 & 12 & 30 & 30 & 50 & 50 & 8 & 8 & 3.54 & 1 & 1 & 4 & 4 & 40 & 40 & 35 & 35 & 20 & 20 & 3.69 \\
\hline $\mathrm{X} 1.5$ & 0 & 0 & 8 & 8 & 12 & 12 & 58 & 58 & 22 & 22 & 3.94 & 0 & 0 & 17 & 17 & 29 & 29 & 41 & 41 & 13 & 13 & 3.5 \\
\hline X1.6 & 0 & 0 & 0 & 0 & 28 & 28 & 38 & 38 & 34 & 34 & 4.06 & 2 & 2 & 8 & 8 & 38 & 38 & 49 & 49 & 3 & 3 & 3.43 \\
\hline X1.7 & 0 & 0 & 2 & 2 & 20 & 20 & 46 & 46 & 32 & 32 & 4.08 & 2 & 2 & 9 & 9 & 26 & 26 & 48 & 48 & 15 & 15 & 3.65 \\
\hline X1.8 & 0 & 0 & 8 & 8 & 12 & 12 & 58 & 58 & 22 & 22 & 3.94 & 1 & 1 & 8 & 8 & 32 & 32 & 43 & 43 & 16 & 16 & 3.65 \\
\hline
\end{tabular}

Sumber: Data Olahan Peneliti (2017)

Kriteria Item:

X1.1 : Kemampuan driver dalam merespon

$\mathrm{X} 1.2$ : Driver tepat waktu sampe ke tujuan

X1.3 : Motor tidak mogok saat mengantar penumpang

X1.4 : Drive melayani sesuai SOP

X1.5 : Aplikasi Wakjek Mudah digunakan

X1.6 : Wakjek dapat diandalkan masyarakat batam

X1.7 : Wakjek menjadi Alternative saat situasi macet

X1.8 : Layanan Wakjek 24 jam

Berdasarkan data olahan pada tabel diatas, pada kolom pertama menunjukan kisaran nilai rata-rata pada reliability $\mathrm{X} 1$ dari item kinerja dengan mean berkisar pada $3.54 \mathrm{~s} / \mathrm{d} 4.08$. Pada variabel reliability merupakan dimensi mengidentifikasi kemampuan melaksanakan jasa keseluruhan indikator menunjukan skor terbesar jawaban responden baik. Hal ini berarti bahwa pelanggan Wakjek setuju dengan kemampuan melaksanakan jasa dengan baik.

Untuk masalah Harapan pada kolom harapan menunjukan mean berkisar pada 3.43 s/d 3.69 menunjukan tingkat harapan pelanggan wakjek berkisar pada jawaban penting, pelanggan Wakjek sangat merespon dari tingkat kinerja sahingga harapan nya terletak di tingkat penting.

\section{Deskripsi Variabel Responsivness (X2)}

Variabel penelitian respon atau kesiapan diukur dengan menggunakan 6 item pertanyaan dari dimensi variabel mengidentifikasi respon dan kesiapan ojek online Wakjek. Berdasarkan data yang terkumpul dari 100 responden mengenai respon dan kesiapan adalah sebagai berikut:

Tabel 2 Variabel Responsivness (X2) Kinerja dan Harapan

\begin{tabular}{|c|c|c|c|c|c|c|c|c|c|c|c|c|c|c|c|c|c|c|c|c|c|c|}
\hline \multirow{4}{*}{ Item } & \multicolumn{21}{|c|}{ Skor Jawaban } & \multirow{4}{*}{ Mean } \\
\hline & \multicolumn{10}{|c|}{ Kinerja } & \multirow{3}{*}{ Mean } & \multicolumn{10}{|c|}{ Harapan } & \\
\hline & \multicolumn{2}{|c|}{1} & \multicolumn{2}{|c|}{2} & \multicolumn{2}{|c|}{3} & \multicolumn{2}{|c|}{4} & \multicolumn{2}{|c|}{5} & & \multicolumn{2}{|c|}{1} & \multicolumn{2}{|c|}{2} & \multicolumn{2}{|c|}{3} & \multicolumn{2}{|c|}{4} & \multicolumn{2}{|c|}{5} & \\
\hline & $\mathrm{f}$ & $\%$ & $\mathrm{f}$ & $\%$ & $\mathrm{f}$ & $\%$ & $\mathrm{f}$ & $\%$ & $f$ & $\%$ & & $\mathrm{f}$ & $\%$ & $\mathrm{f}$ & $\%$ & $\mathrm{f}$ & $\%$ & $\mathrm{f}$ & $\%$ & $\mathrm{f}$ & $\%$ & \\
\hline $\mathrm{X} 2.1$ & 0 & 0 & 0 & 0 & 28 & 28 & 38 & 38 & 34 & 34 & 4.06 & 1 & 1 & 13 & 13 & 24 & 24 & 48 & 48 & 14 & 14 & 3.61 \\
\hline $\mathrm{X} 2.2$ & 0 & 0 & 2 & 2 & 20 & 20 & 46 & 46 & 32 & 32 & 4.08 & 0 & 0 & 8 & 8 & 34 & 34 & 39 & 39 & 19 & 19 & 3.69 \\
\hline $\mathrm{X} 2.3$ & 0 & 0 & 3 & 3 & 13 & 13 & 56 & 56 & 28 & 28 & 4.09 & 0 & 0 & 6 & 6 & 34 & 34 & 39 & 39 & 21 & 21 & 3.75 \\
\hline $\mathrm{X} 2.4$ & 0 & 0 & 3 & 3 & 30 & 30 & 47 & 47 & 20 & 20 & 3.84 & 0 & 0 & 8 & 8 & 29 & 29 & 47 & 47 & 16 & 16 & 3.71 \\
\hline $\mathrm{X} 2.5$ & 0 & 0 & 0 & 0 & 12 & 12 & 59 & 59 & 29 & 29 & 4.17 & 0 & 0 & 7 & 7 & 13 & 13 & 59 & 59 & 21 & 21 & 3.94 \\
\hline $\mathrm{X} 2.6$ & 0 & 0 & 4 & 4 & 20 & 20 & 54 & 54 & 22 & 22 & 3.94 & 0 & 0 & 2 & 2 & 27 & 27 & 39 & 39 & 32 & 32 & 4.01 \\
\hline
\end{tabular}

Sumber: Data Olahan Peneliti (2017)

Kriteria Item:

X2.1 : Driver mengkonfirmasi melalui aplikasi

$\mathrm{X} 1.2$ : Driver memberikan kesan poditif

$\mathrm{X} 1.3$ : Driver menjawab pertanyaan pelanggan dengan baik
X1.4 : Driver mengantar dengan cepat sampai ketujuan

X1.5 : Driver memberi respon cepat dalam mengatasi kemacetan

X1.6 : Wakjek bisa melayani kapanpun dibutuhkan 
Berdasarkan data olahan pada tabel diatas, pada kolom kinerja menunjukan kisaran nilai rata-rata pada X2 yaitu kehandalan dari item kepentingan berkisar antara 3,84 s/d 4,17. Pada variabel kinerja (X2) merupakan respon atau kesiapan karyawan dalam membantu pelanggan dengan indikator menunjukan skor terbesar jawaban responden baik. Hal ini berarti bahwa pelanggan Wakjek setuju dan mengharapkan kinerja dalam memberikan pelayanan dengan segera, akurat, dan memuaskan yang diberikan oleh Driver maupun perusahaan Wakjek.

Pada kolom kedua merupakan variabel Harapan dari item Harapan. Item Harapan menunjukan nilai mean pada kisaran 3,61 s/d
4,01. Pada indikator X2.1, X2.4, X2.5, X2.6 yakni menunjukan lebih dari 40 responden menganggap penting dari harapan pelanggan atas kinerja dari wakjek dalam merespon dan memberikan pelayanan kepada pelanggan.

\section{Deskripsi Variabel Assurance (X3)}

Variabel penelitian assurance diukur dengan menggunakan 9 item pertanyaan dari dimensi variabel mengidentifikasi kemampuan karyawan saat memberi layanana kepada pelanggan. Berdasarkan data yang terkumpul dari 100 responden mengenai kemampuan karyawan memberikan pelayanana antara kinerja dan harapan adalah sebagai berikut:

Tabel 3 Variabel Assurance (X3) Kinerja dan Harapan

\begin{tabular}{|c|c|c|c|c|c|c|c|c|c|c|c|c|c|c|c|c|c|c|c|c|c|c|}
\hline \multirow{4}{*}{ Item } & \multicolumn{21}{|c|}{ Skor Jawaban } & \multirow{4}{*}{ Mean } \\
\hline & \multicolumn{10}{|c|}{ Kinerja } & \multirow{3}{*}{ Mean } & \multicolumn{10}{|c|}{ Harapan } & \\
\hline & \multicolumn{2}{|c|}{1} & \multicolumn{2}{|c|}{2} & \multicolumn{2}{|c|}{3} & \multicolumn{2}{|c|}{4} & \multicolumn{2}{|c|}{5} & & \multicolumn{2}{|c|}{1} & \multicolumn{2}{|c|}{2} & \multicolumn{2}{|c|}{3} & \multicolumn{2}{|c|}{4} & \multicolumn{2}{|c|}{5} & \\
\hline & $\mathrm{f}$ & $\%$ & $\mathrm{f}$ & $\%$ & $\mathrm{f}$ & $\%$ & $\mathrm{f}$ & $\%$ & $\mathrm{f}$ & $\%$ & & $\mathrm{~F}$ & $\%$ & $\mathrm{f}$ & $\%$ & $\mathrm{f}$ & $\%$ & $\mathrm{f}$ & $\%$ & $\mathrm{f}$ & $\%$ & \\
\hline X3.1 & 0 & 0 & 2 & 2 & 6 & 6 & 13 & 13 & 79 & 79 & 4.69 & 0 & 0 & 1 & 1 & 17 & 17 & 50 & 50 & 32 & 32 & 4.13 \\
\hline $\mathrm{X} 3.2$ & 0 & 0 & 2 & 2 & 6 & 6 & 23 & 23 & 69 & 69 & 4.59 & 0 & 0 & 7 & 7 & 15 & 15 & 55 & 55 & 23 & 23 & 4 \\
\hline X3.3 & 0 & 0 & 1 & 1 & 10 & 10 & 19 & 19 & 70 & 70 & 4.58 & 0 & 0 & 0 & 0 & 26 & 26 & 40 & 40 & 34 & 34 & 4.08 \\
\hline X3.4 & 0 & 0 & 11 & 11 & 47 & 47 & 38 & 38 & 4 & 4 & 3.35 & 0 & 0 & 1 & 1 & 24 & 24 & 45 & 45 & 30 & 30 & 4.04 \\
\hline X3.5 & 0 & 0 & 10 & 10 & 41 & 41 & 46 & 46 & 3 & 3 & 3.42 & 0 & 0 & 2 & 2 & 20 & 20 & 56 & 56 & 22 & 22 & 3.98 \\
\hline X3.6 & 0 & 0 & 12 & 12 & 45 & 45 & 38 & 38 & 5 & 5 & 3.36 & 0 & 0 & 4 & 4 & 20 & 20 & 50 & 50 & 26 & 26 & 3.98 \\
\hline X3.7 & 2 & 2 & 5 & 5 & 40 & 40 & 35 & 35 & 18 & 18 & 3.62 & 0 & 0 & 0 & 0 & 24 & 24 & 68 & 68 & 8 & 8 & 3.84 \\
\hline X3.8 & 0 & 0 & 5 & 5 & 4 & 4 & 20 & 20 & 71 & 71 & 4.57 & 0 & 0 & 12 & 12 & 30 & 30 & 50 & 50 & 8 & 8 & 3.54 \\
\hline X3.9 & 3 & 3 & 9 & 9 & 36 & 36 & 52 & 52 & 0 & 0 & 3.37 & 0 & 0 & 8 & 8 & 12 & 12 & 58 & 58 & 22 & 22 & 3.94 \\
\hline
\end{tabular}

Sumber: Data Olahan Peneliti (2017)

Kriteria Item:

X3.1 : Driver menggemudi dengan hati-hati

X3.2 : Driver dapat mengendarai dalam situasi hujan

X3.3 : Driver memahami dan mematuhi rambu-rambu lalu lintas

X3.4 : Driver memberikan senyum dan sapaan

X3.5 : Driver berbicara dengan sopan

X3.6 : Driver bersikap sopan

X3.7 : Wakjek dapat mengantar penumpang dalam situasi macet

X3.8 : Wakjek dapat diandalkan saat hujan

X3.9 : Tidak pernah mendengar isu negative dari layanan Wakjek

Berdasarkan data olahan pada tabel diatas, pada kolom kinerja menunjukan kisaran nilai rata-rata pada X3 yaitu assurance dari item kinerja berkisar antara 3,35 s/d 4,69. Pada variabel assurance (X3) merupakan dimensi mengidentifikasi assurance para petugas untuk melayani keinginan para pelanggan Wakjek.
Pelanggan merasa kinerja dari Wakjek baik dikarenakan rata-rata pelanggan banyak yang menjawab pada indikator baik.

Pada kolom kedua merupakan variabel assurance item harapan dimana nilai rata-rata pada kolom harapan berkisar antara 3,54 s/d 4,13 dengan tingkat harapan banyak yang memilih jawaban penting, berarti menunjukan bahwa pelanggan dari ojek online Wakjek merasa bahwa Wakjek perlu untuk terus memberikan pelayanan maupun kemampuan untuk memiliki pengetahuah, kesopanan dan sifat dapat dipercaya oleh pelanggan Wakjek.

\section{Deskripsi Variabel Emphaty (X4)}

Variabel penelitian emphaty diukur dengan menggunakan 8 item pertanyaan dari dimensi variabel mengidentifikasi emphaty Wakjek kepada pelanggan ojek online Wakjek. Berdasarkan data yang terkumpul dari 100 responden mengenai emphaty antara kinerja dan harapan adalah sebagai berikut: 
Yovan \& Shinta, Analisis Kepuasan Pelanggan...

Tabel 4 Variabel Emphaty (X4) Kinerja dan Harapan

\begin{tabular}{|c|c|c|c|c|c|c|c|c|c|c|c|c|c|c|c|c|c|c|c|c|c|c|}
\hline \multirow{4}{*}{ Item } & \multicolumn{21}{|c|}{ Skor Jawaban } & \multirow{4}{*}{ Mean } \\
\hline & \multicolumn{10}{|c|}{ Kinerja } & \multirow{3}{*}{ Mean } & \multicolumn{10}{|c|}{ Harapan } & \\
\hline & \multicolumn{2}{|c|}{1} & \multicolumn{2}{|c|}{2} & \multicolumn{2}{|c|}{3} & \multicolumn{2}{|c|}{4} & \multicolumn{2}{|c|}{5} & & \multicolumn{2}{|c|}{1} & \multicolumn{2}{|c|}{2} & \multicolumn{2}{|c|}{3} & \multicolumn{2}{|c|}{4} & \multicolumn{2}{|c|}{5} & \\
\hline & $\mathrm{f}$ & $\%$ & $\mathrm{f}$ & $\%$ & $\mathrm{f}$ & $\%$ & $\mathrm{f}$ & $\%$ & $\mathrm{f}$ & $\%$ & & $\mathrm{f}$ & $\%$ & $\mathrm{f}$ & $\%$ & $\mathrm{f}$ & $\%$ & $\mathrm{f}$ & $\%$ & $\mathrm{f}$ & $\%$ & \\
\hline $\mathrm{X} 4.1$ & 3 & 3 & 13 & 13 & 33 & 33 & 49 & 49 & 2 & 2 & 3.34 & 0 & 0 & 0 & 0 & 28 & 28 & 38 & 38 & 34 & 34 & 4.06 \\
\hline $\mathrm{X} 4.2$ & 4 & 4 & 16 & 16 & 34 & 34 & 44 & 44 & 2 & 2 & 324 & 0 & 0 & 2 & 2 & 20 & 20 & 46 & 46 & 32 & 32 & 4.08 \\
\hline $\mathrm{X} 4.3$ & 4 & 4 & 6 & 6 & 36 & 36 & 36 & 36 & 18 & 18 & 3.58 & 0 & 0 & 8 & 8 & 12 & 12 & 58 & 58 & 22 & 22 & 3.94 \\
\hline $\mathrm{X} 4.4$ & 2 & 2 & 10 & 10 & 30 & 30 & 45 & 45 & 13 & 13 & 3.57 & 0 & 0 & 0 & 0 & 28 & 28 & 38 & 38 & 34 & 34 & 4.06 \\
\hline $\mathrm{X} 4.5$ & 1 & 1 & 10 & 10 & 36 & 36 & 39 & 39 & 14 & 14 & 3.55 & 0 & 0 & 2 & 2 & 20 & 20 & 46 & 46 & 32 & 32 & 4.08 \\
\hline $\mathrm{X} 4.6$ & 1 & 1 & 14 & 14 & 23 & 23 & 51 & 51 & 11 & 11 & 3.57 & 0 & 0 & 3 & 3 & 13 & 13 & 56 & 56 & 28 & 28 & 4.09 \\
\hline $\mathrm{X} 4.7$ & 0 & 0 & 8 & 8 & 37 & 37 & 38 & 38 & 17 & 17 & 3.64 & 0 & 0 & 3 & 3 & 30 & 30 & 47 & 47 & 20 & 20 & 3.84 \\
\hline $\mathrm{X} 4.8$ & 0 & 0 & 9 & 9 & 36 & 36 & 39 & 39 & 16 & 16 & 3.62 & 0 & 0 & 0 & 0 & 12 & 12 & 59 & 59 & \begin{tabular}{|l|}
29 \\
\end{tabular} & 29 & 4.17 \\
\hline
\end{tabular}

Sumber: Data Olahan Peneliti (2017)

Kriteria Item:

X4.1 : Kemudahaan dalam memesan online

$\mathrm{X} 4.2$ : Kemudahaan lewat via telfon

$\mathrm{X} 4.3$ : Driver memiliki wawasan tentang rute yang harus dilewati

X4.4 : Drive berkomunikasi dengan Bahasa yang sopan

X4.5 : Driver menyediakan helm untuk penumpang

X4.6 : Perusahaan merespon dengan cepat keluhan pelanggan

X4.7 : Driver menyediakan jas hujan

$\mathrm{X} 4.8$ : Wakjek memasang tarif jelas dan murah

Berdasarkan data olahan pada tabel diatas, pada kolom kinerja menunjukan kisaran nilai rata-rata pada X4 yaitu berkisar antara 3,24 s/d 3,64. Pada variabel emphaty (X4) merupakan dimensi mengidentifikasi perhatian yang diberikan dari perusahaan maupun driver Wakjek, secara umum indikator menunjukan skor terbesar jawaban responden cukup baik dan baik. Hal ini berarti bahwa pelanggan
Wakjek setuju dan merasakan kinerja dari ojek online Wakjek baik dari dimensi emphaty.

Pada kolom kedua merupakan variable harapan yang diberikan oleh pelanggan Wakjek. Item harapan menunjukan nilai mean pada kisaran 3,84 s/d 4,17. Pada item harapan jika dibandingkan dengan kinerja responden nilai rata-rata kinerja lebih kecil ketimbang harapan, berarti pelanggan wakjek masih mengharapkan kinerja yang lebih yang harus diberikan Wakjek dalam indikator emphty.

\section{Deskripsi Variabel Tangible (X5)}

Variabel penelitian tangible diukur dengan menggunakan 6 item pertanyaan dari dimensi variabel mengidentifikasi bukti fisik yang diberikan oleh ojek online Wakjek. Berdasarkan data yang terkumpul dari 100 responden mengenai bukti fisik antara kinerja dan harapan ojek online Wakjek adalah sebagai berikut:

Tabel 5 Variabel Tangible (X5) Kinerja dan Harapan

\begin{tabular}{|c|c|c|c|c|c|c|c|c|c|c|c|c|c|c|c|c|c|c|c|c|c|c|}
\hline \multirow{4}{*}{ Item } & \multicolumn{21}{|c|}{ Skor Jawaban } & \multirow{4}{*}{ Mean } \\
\hline & \multicolumn{10}{|c|}{ Kinerja } & \multirow{3}{*}{ Mean } & \multicolumn{10}{|c|}{ Harapan } & \\
\hline & \multicolumn{2}{|c|}{1} & \multicolumn{2}{|c|}{2} & \multicolumn{2}{|c|}{3} & \multicolumn{2}{|c|}{4} & \multicolumn{2}{|c|}{5} & & \multicolumn{2}{|c|}{1} & \multicolumn{2}{|c|}{2} & \multicolumn{2}{|c|}{3} & \multicolumn{2}{|c|}{4} & \multicolumn{2}{|c|}{5} & \\
\hline & f & $\%$ & $\mathrm{f}$ & $\%$ & $\mathrm{f}$ & $\%$ & $\mathrm{f}$ & $\%$ & $\mathrm{f}$ & $\%$ & & $\mathrm{f}$ & $\%$ & $\mathrm{f}$ & $\%$ & $\mathrm{f}$ & $\%$ & $\mathrm{f}$ & $\%$ & $\mathrm{f}$ & $\%$ & \\
\hline $\mathrm{X} 5.1$ & 0 & 0 & 10 & 10 & 33 & 33 & 46 & 46 & 11 & 11 & 3.58 & 0 & 0 & 4 & 4 & 20 & 20 & 54 & 54 & 22 & 22 & 3.94 \\
\hline $\mathrm{X} 5.2$ & 0 & 0 & 0 & 0 & 10 & 10 & 23 & 23 & 67 & 67 & 4.57 & 0 & 0 & 0 & 0 & 4 & 4 & 56 & 56 & 40 & 40 & 4.36 \\
\hline $\mathrm{X} 5.3$ & 0 & 0 & 4 & 4 & 10 & 10 & 18 & 18 & 68 & 68 & 4.5 & 0 & 0 & 2 & 2 & 30 & 30 & 47 & 47 & 21 & 21 & 3.87 \\
\hline $\mathrm{X} 5.4$ & 0 & 0 & 0 & 0 & 9 & 9 & 28 & 28 & 63 & 63 & 4.54 & 0 & 0 & 2 & 2 & 19 & 19 & 51 & 51 & 28 & 28 & 4.05 \\
\hline X5.5 & 0 & 0 & 2 & 2 & 6 & 6 & 13 & 13 & 79 & 79 & 4.69 & 0 & 0 & 11 & 11 & 47 & 47 & 38 & 38 & 4 & 4 & 3.35 \\
\hline X5.6 & 0 & 0 & 1 & 1 & 8 & 8 & 11 & 11 & 80 & 80 & 4.7 & 0 & 0 & 10 & 10 & 41 & 41 & 46 & 46 & 3 & 3 & 3.42 \\
\hline
\end{tabular}

Sumber: Data Olahan Peneliti (2017)

Kriteria Item:

X5.1 : Keadaan motor dalam keadaan baik dan bersih

X5.2 : Kondisi motor nyaman untuk dinaiki
X5.3 : Kelengkapan motor sesuai standar

X5.4 : Drive selalu tampil bersih, rapi, harum dan wangi 
X5.5 : Driver selalu menggunakan seragam Wakjek

X5.6 : Driver selalu menggunakan helm saat mengantar pelanggan

Berdasarkan data olahan pada tabel diatas, pada kolom kinerja menunjukan kisaran nilai rata-rata pada X5 yaitu tangible dari item kinerja berkisar antara 3,58 s/d 4,95 Pada variabel tangible (X5) merupakan dimensi mengidentifikasi segala bukti fisik, fasilitas, peralatan, maupun tampilan fisik kendaraan. indikator menunjukan skor terbesar jawaban responden baik dan sangat baik. Hal ini berarti bahwa pelanggan Wakjek telah merasakan kinerja yang sangat baik dari indikator tangible dengan skor tertinggi terdapat pada jawaban sangat baik dengan presentase $80 \%$.

Pada kolom kedua merupakan variabel tangible dari item harapan atau. Item harapan menunjukan nilai mean pada kisaran 3,35 s/d 4,36. Pada item harapan jika dibandingkan dengan kinerja responden nilai rata-rata kinerja menunjukan angka diatas harapan. Dapat dikatakan bahwa pelanggan ojek online Wakjek telah merasakan kinerja dari Wakjek dengan sangat baik.

\section{Deskripsi Variabel Kepuasan Pelayanan (Y)}

Variabel penelitian kepuasan pelayanan (Y) diukur dengan menggunakan 4 item pertanyaan dari pelayanan dari ojek online Wakjek Di Kota Batam. Berdasarkan data yang terkumpul dari 100 responden mengenai kepuasan pelanggan dari Wakjek antara kinerja dan harapan adalah sebagai berikut:

Tabel 6 Variabel Kepuasan Pelayanan (Y) Kinerja dan Harapan

\begin{tabular}{|c|c|c|c|c|c|c|c|c|c|c|c|c|c|c|c|c|c|c|c|c|c|c|}
\hline \multirow{4}{*}{ Item } & \multicolumn{21}{|c|}{ Skor Jawaban } & \multirow{4}{*}{ Mean } \\
\hline & \multicolumn{10}{|c|}{ Kinerja } & \multirow{3}{*}{ Mean } & \multicolumn{10}{|c|}{ Harapan } & \\
\hline & \multicolumn{2}{|c|}{1} & \multicolumn{2}{|c|}{2} & \multicolumn{2}{|c|}{3} & \multicolumn{2}{|c|}{4} & \multicolumn{2}{|c|}{5} & & \multicolumn{2}{|c|}{1} & \multicolumn{2}{|c|}{2} & \multicolumn{2}{|c|}{3} & \multicolumn{2}{|c|}{4} & \multicolumn{2}{|c|}{5} & \\
\hline & $\mathrm{f}$ & $\%$ & $\mathrm{f}$ & $\%$ & $\mathrm{f}$ & $\%$ & $\mathrm{f}$ & $\%$ & $\mathrm{f}$ & $\%$ & & $\mathrm{f}$ & $\%$ & $\mathrm{f}$ & $\%$ & $\mathrm{f}$ & $\%$ & $\mathrm{f}$ & $\%$ & $\mathrm{f}$ & $\%$ & \\
\hline Y1.1 & 0 & 0 & 3 & 3 & 4 & 4 & 8 & 8 & 85 & 85 & 4.75 & 0 & 0 & 12 & 12 & 45 & 45 & 38 & 38 & 5 & 5 & 3.36 \\
\hline Y1.2 & 0 & 0 & 3 & 3 & 4 & 4 & 6 & 6 & 87 & 87 & 4.77 & 2 & 2 & 5 & 5 & 40 & 40 & 35 & 35 & 18 & 18 & 3.62 \\
\hline Y1.3 & 0 & 0 & 3 & 3 & 6 & 6 & 9 & 9 & 82 & 82 & 4.7 & 0 & 0 & 18 & 18 & 35 & 35 & 36 & 36 & 11 & 11 & 3.4 \\
\hline Y1.4 & 0 & 0 & 6 & 6 & 1 & 1 & 10 & 10 & 83 & 83 & 4.7 & 3 & 3 & 9 & 9 & 36 & 36 & 52 & 52 & 0 & 0 & 3.37 \\
\hline
\end{tabular}

Sumber: Data Olahan Peneliti (2017)

Kriteria Item:

Y1.1 : Jasa yang ditawarkan sesuai ekspetasi pelanggan

Y1.2 : Kinerja driver Wakjek Sesuai SOP perusahaan

Y1.3 : Wakjek dapat diandalakan untuk menggurangi kemacetan

Y1.4 : Layanan Wakjek dapat diandalkan dalam jasa transportasi di Kota Batam

Berdasarkan data olahan pada tabel diatas, pada kolom kinerja menunjukan kisaran nilai rata-rata pada Y yaitu kinerja dari ojek online Wakjek berkisar antara 4,7 s/d 4,75. Variabel ini menggambarkan kepuasan pelayanan secara keseluruhan yang dirasakan oleh responden mengenai ojek online Wakjek
Seperti yang terlihat pada kolom kinerja diatas menggambarkan kinerja secara keseluruhan mengenai kepuasan pelayanan yang diinginkan responden cukup tinggi dengan persentase $87 \%$ mengatakan kinerja dari ojek online Wakjek sudah sangat baik.

Pada kolom kedua merupakan variabel kepuasan pelayanan dari item harapan yang dirasakan oleh responden. Item harapan menunjukan nilai mean pada kisaran $3,4 \mathrm{~s} / \mathrm{d}$ 3,62. Pada item harapan jika dibandingkan dengan kinerja responden nilai rata-rata kinerja juga menunjukan angka yang sangat tinggi. Dimana dapat dikatakan untuk kepuasan pelanggan dengan indikator kinerja telah melebihi harapan yang dibangun oleh responden. 
Yovan \& Shinta, Analisis Kepuasan Pelanggan...

\section{Tingkat Kepuasan Konsumen}

Tabel 1 Tingkat Kesesuaian Rata-Rata antara Kinerja dan Harapan

\begin{tabular}{|c|c|c|c|c|c|}
\hline No & Nama Atribut & $\begin{array}{l}\text { Tingkat } \\
\text { Kesesuaian }\end{array}$ & $\begin{array}{c}\text { Rata- } \\
\text { rata } \\
\text { Harapan }\end{array}$ & $\begin{array}{l}\text { Rata- } \\
\text { rata } \\
\text { Kinerja }\end{array}$ & GAP \\
\hline 1 & $\begin{array}{l}\text { Kemampuan driver untuk merespon order dari } \\
\text { penumpang }\end{array}$ & 115.36 & 3.45 & 3.98 & 0.87 \\
\hline 2 & Driver tepat waktu sampai ketujuan pemesan & 113.07 & 3.52 & 3.98 & 0.88 \\
\hline 3 & $\begin{array}{l}\text { Motor tidak mogok pada saat mengantar } \\
\text { penumpang }\end{array}$ & 110.66 & 3.47 & 3.84 & 0.90 \\
\hline 4 & $\begin{array}{l}\text { Driver melayani penumpang/pelanggan sesuai } \\
\text { dengan SOP dari perusahaan Wakjek }\end{array}$ & 95.93 & 3.69 & 3.54 & 1.04 \\
\hline 5 & $\begin{array}{l}\text { Aplikasi dari Wakjek mudah digunakan saat } \\
\text { melakukan pemesanan }\end{array}$ & 112.57 & 3.5 & 3.94 & 0.89 \\
\hline 6 & $\begin{array}{l}\text { Jasa transportasi wakjek dapat diandalkan oleh } \\
\text { masyarakat Batam }\end{array}$ & 118.37 & 3.43 & 4.06 & 0.84 \\
\hline 7 & $\begin{array}{l}\text { Wakjek menjadi alternative anda untuk sampai } \\
\text { ketujuan pada saat situasi macet }\end{array}$ & 111.78 & 3.65 & 4.08 & 0.89 \\
\hline 8 & Layanan operasional Wakjek 24 jam & 107.95 & 3.65 & 3.94 & 0.93 \\
\hline 9 & $\begin{array}{l}\text { Driver merespon dengan cara mengkonfirmasi } \\
\text { order dari pemesan melalui aplikasi }\end{array}$ & 112.47 & 3.61 & 4.06 & 0.89 \\
\hline 10 & $\begin{array}{l}\text { Driver memberikan kesan positif saat bertemu } \\
\text { dengan penumpang/pelanggan }\end{array}$ & 110.57 & 3.69 & 4.08 & 0.90 \\
\hline 11 & $\begin{array}{l}\text { Driver menjawab pertanyaan pelanggan dengan } \\
\text { baik }\end{array}$ & 109.07 & 3.75 & 4.09 & 0.92 \\
\hline 12 & $\begin{array}{l}\text { Driver mengantar pelanggan dengan cepat } \\
\text { sampai ketujuan }\end{array}$ & 103.50 & 3.71 & 3.84 & 0.97 \\
\hline 13 & $\begin{array}{l}\text { Driver memberikan respon cepat dengan mencari } \\
\text { alternative jalan dalam kondisi macet dan } \\
\text { terdekat }\end{array}$ & 105.84 & 3.94 & 4.17 & 0.94 \\
\hline 14 & $\begin{array}{l}\text { Driver Wakjek bisa melayani kapanpun } \\
\text { dibutuhkan }\end{array}$ & 98.25 & 4.01 & 3.94 & 1.02 \\
\hline 15 & $\begin{array}{l}\text { Driver Wakjek mengemudi motor dengan hati- } \\
\text { hati sehingga penumpang merasa aman }\end{array}$ & 113.56 & 4.13 & 4.69 & 0.88 \\
\hline 16 & $\begin{array}{l}\text { Driver Wakjek dapat mengendarai dalam situasi } \\
\text { hujan }\end{array}$ & 116.50 & 3.94 & 4.59 & 0.86 \\
\hline 17 & $\begin{array}{l}\text { Driver Wakjek memahami dan mematuhi rambu- } \\
\text { rambu lalulintas }\end{array}$ & 112.25 & 4.08 & 4.58 & 0.89 \\
\hline 18 & $\begin{array}{l}\text { Driver Wakjek memberikan sapaan dan } \\
\text { senyuman saat awal bertemu penumpang }\end{array}$ & 82.92 & 4.04 & 3.35 & 1.21 \\
\hline 19 & $\begin{array}{l}\text { Driver selalu berbicara dengan sopan kepada } \\
\text { pelanggan selama diperjalanan }\end{array}$ & 85.93 & 3.98 & 3.42 & 1.16 \\
\hline 20 & Driver bersikap sopan selama diperjalanan & 84.42 & 3.98 & 3.36 & 1.18 \\
\hline 21 & $\begin{array}{l}\text { Wakjek dapat diandalkan saat mengantarkan } \\
\text { penumpang dalam situasi macet }\end{array}$ & 94.27 & 3.84 & 3.62 & 1.06 \\
\hline 22 & $\begin{array}{l}\text { Wakjek dapat diandalkan saat mengantar } \\
\text { penumpang dalam situasi hujan }\end{array}$ & 129.10 & 3.54 & 4.57 & 0.77 \\
\hline 23 & $\begin{array}{l}\text { Tidak pernah mendengar isu negatif dari layanan } \\
\text { Wakjek }\end{array}$ & 85.53 & 3.94 & 3.37 & 1.17 \\
\hline 24 & $\begin{array}{l}\text { Pelanggan merasa mudah untuk memesan } \\
\text { Wakjek dalam sistem online }\end{array}$ & 82.27 & 4.06 & 3.34 & 1.22 \\
\hline 25 & Kemudahan menghubungi dalam via telefon & 79.41 & 4.08 & 3.24 & 1.26 \\
\hline 26 & $\begin{array}{l}\text { Driver Wakjek memiliki wawasan tentang rute } \\
\text { jalan yang harus dilalui oleh Wakjek }\end{array}$ & 88.83 & 3.94 & 3.5 & 1.13 \\
\hline 27 & $\begin{array}{l}\text { Driverberkomunikasi dengan mengunakan } \\
\text { bahasa sopan }\end{array}$ & 87.93 & 4.06 & 3.57 & 1.14 \\
\hline 28 & $\begin{array}{l}\text { DriverWakjek menyediakan helm untuk } \\
\text { penumpang/pelanggan }\end{array}$ & 87.01 & 4.08 & 3.55 & 1.15 \\
\hline 29 & Perusahaan Wakjek selalu merespon dengan & 87.29 & 4.09 & 3.57 & 1.15 \\
\hline
\end{tabular}


Journal of Applied Business Administration Vol 1, No 1, Maret 2017, hlm. 96-121

\begin{tabular}{|c|c|c|c|c|c|}
\hline & cepat keluhan dari pelanggan & & & & \\
\hline 30 & $\begin{array}{l}\text { Anda yakin bahwa driver Wakjek menyediakan } \\
\text { jas hujan }\end{array}$ & 94.79 & 3.84 & 3.64 & 1.05 \\
\hline 31 & $\begin{array}{l}\text { Wakjek memasang tarif yang jelas dan murah } \\
\text { sesuai dengan tujuan penumpang }\end{array}$ & 86.81 & 4.17 & 3.62 & 1.15 \\
\hline 32 & $\begin{array}{l}\text { Keadaan motor yang dipakai Wakjek dalam } \\
\text { keadaan baik dan bersih }\end{array}$ & 90.86 & 3.94 & 3.58 & 1.10 \\
\hline 33 & $\begin{array}{l}\text { Kondisi motor Wakjek dalam keadaan baik } \\
\text { sehingga nyaman untuk dinaiki }\end{array}$ & 104.82 & 4.36 & 4.57 & 0.95 \\
\hline 34 & $\begin{array}{l}\text { Kelengkapan motor sesuai standar yang telah } \\
\text { ditetapkan }\end{array}$ & 116.28 & 3.87 & 4.5 & 0.86 \\
\hline 35 & $\begin{array}{l}\text { Driver selalu tampil bersih, rapi, harum dan } \\
\text { wangi }\end{array}$ & 112.10 & 4.05 & 4.54 & 0.89 \\
\hline 36 & $\begin{array}{l}\text { Driver selalu menggunakan seragam yang mudah } \\
\text { dikenali oleh pelanggan }\end{array}$ & 140.00 & 3.35 & 4.69 & 0.71 \\
\hline 37 & $\begin{array}{l}\begin{array}{l}\text { Driver selalu } \\
\text { mengendarai } \\
\text { menggunakan }\end{array} \text { helm saat } \\
\text { penumpang }\end{array}$ & 137.43 & 3.42 & 4.7 & 0.73 \\
\hline 38 & $\begin{array}{l}\text { Jasa yang ditawarkan Wakjek sesuai ekspetasi } \\
\text { pelanggan }\end{array}$ & 141.37 & 3.36 & 4.75 & 0.71 \\
\hline 39 & $\begin{array}{l}\text { Kinerja driver Wakjek dilapangan sesuai SOP } \\
\text { perusahaan }\end{array}$ & 131.77 & 3.62 & 4.77 & 0.76 \\
\hline 40 & $\begin{array}{l}\text { Wakjek dapat diandalkan dalam menguranggi } \\
\text { kemacetan }\end{array}$ & 138.24 & 3.4 & 4.7 & 0.72 \\
\hline 41 & $\begin{array}{l}\text { Layanan Wakjek dapat diandalkan dalam jasa } \\
\text { transportasi di Kota Batam }\end{array}$ & 124.63 & 3.37 & 4.2 & 0.80 \\
\hline \multicolumn{2}{|c|}{ Rata - Rata } & 106.38 & 3.80 & 4.00 & 0.95 \\
\hline
\end{tabular}

Sumber: Data Olahan Peneliti (2017)

Tabel diatas menjelaskan tingkat kesesuaian antara tingkat kinerja dan harapan , jika persentase $<80 \%$ maka dikatakan bahwa kinerja dari masing-masing atribut tidak dapat memenuhi harapan dari responden, jika persentase $80-100 \%$ maka dikatakan kinerja dari masing-msing indikator telah dapat memenuhi harapan dari konsumen tetapi masih perlu diperbaiki lagi, dan jika persentase $>100 \%$ dapat dikatakan kinerja indikator tersebut telah melebihi dengan harapan konsumen Indrawingsih dan Sudrayanto (2007).

Pada tabel tingkat kesesuaian rata-rata sebesar $106.38 \%$ dengan rentang nilai pada kisaran $79.41 \%$ s/d $141.37 \%$. Atribut yang memiliki nilai sebesar $79.41 \%$ yaitu atribut nomor 25 merupakan atribut dari Kemudahan menghubungi dalam via telefon masih belum sesuai dengan apa yang diharapkan oleh para konsumen dari ojek online Wakjek dan masih perlu dilakukan perbaikan. Atribut yang memiliki nilai $141.37 \%$ adalah atribut nomor 38 yaitu jasa yang ditawarkan Wakjek sesuai ekspetasi pelanggan sangat sesuai dengan harapan sehingga pihak perusahaan Wakjek perlu mempertahankan kualitasnya.
Berdasarkan tabel di atas, tingkat kepuasan pengguna ojek online Wakjek mempunyai gap rata-rata 0,71 artinya tingkat kepuasan pelanggan berada pada kondisi "cukup puas" terhadap masing-masing dimensi.

Nilai rata-rata tingkat Kinerja sebesar 4,00 dan rata-rata tingkat Harapan sebesar 3,80. Nilai rata-rata tersebut akan digunakan dalam menentukan diagram kartesius. Berikut penjabaran kuadran importance performance analysis: 


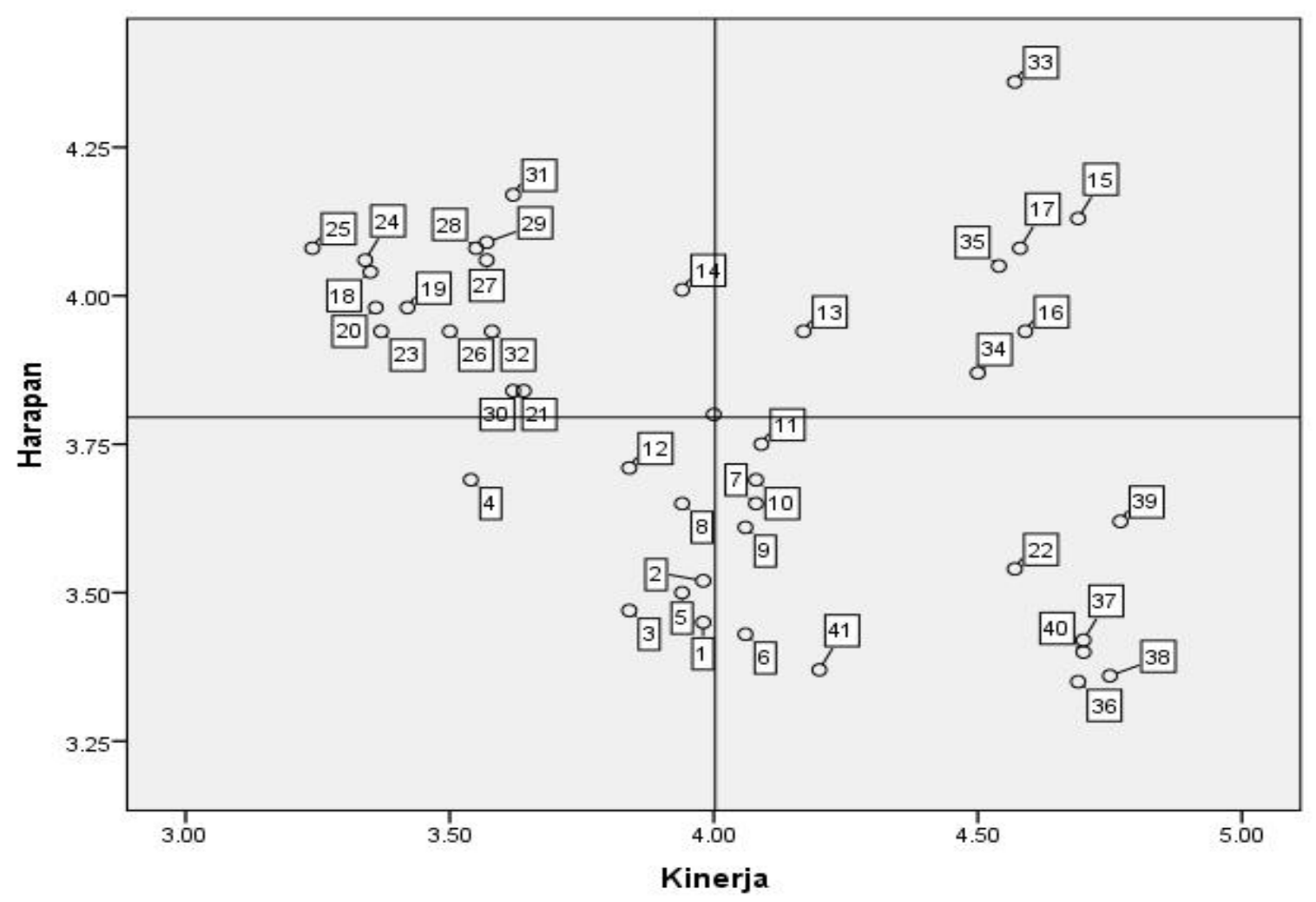

\section{Gambar Penjabaran Indikator dalam Diagram Kartesius \\ Sumber: Data Olahan SPSS, 20 (2017)}

Berdasarkan gambar penjabaran atribut dalam diagram kartesius diatas meggambarkan keadaan yang berbeda. Pemetaan berdasarkan tingkat Kinerja dan harapan memungkinkan pihak Wakjek untuk segera melakukan perbaikan pada atribut yang dianggap penting oleh pelanggan. Pejelasan setiap kuadran adalah sebagai berikut:

\section{Kuadaran A (Prioritas Utama)}

Pada kuadran ini merupakan prioritas utama dimana responden merasakan atribut yang sangat penting tetapi merasakan tidak puas terhadap kinerja yang diberikan oleh pihak Wakjek. Adapun atribut tersebut adalah:

a. Parnyataan nomor 14 yang menyatakan Driver Wakjek bisa melayani kapanpun dibutuhkan

b. Pernyataan nomor 18 yang menyatakan Driver Wakjek memberikan sapaan dan senyuman saat awal bertemu penumpang

c. Pernyataan nomor 19 yang menyatakan Driver selalu berbicara dengan sopan kepada pelanggan selama diperjalanan d. Pernyataan nomor 20 yang menyatakan Driver bersikap sopan selama diperjalanan

e. Pernyataan nomor 21 yang menyatakan Wakjek dapat diandalkan saat mengantarkan penumpang dalam situasi macet

f. Pernyataan nomor 23 yang menyatakan Tidak pernah mendengar isu negatif dari layanan Wakjek

g. Pernyataan nomor 24 yang menyatakan Pelanggan merasa mudah untuk memesan Wakjek dalam sistem online

h. Pernyataan nomor 25 yang menyatakan Kemudahan menghubungi dalam via telefon

i. Pernyataan nomor 26 yang menyatakan Driver Wakjek memiliki wawasan tentang rute jalan yang harus dilalui oleh Wakjek

j. Pernyataan nomor 27 yang menyatakan Driver berkomunikasi dengan mengunakan bahasa sopan

k. Pernyataan nomor 28 yang menyatakan Driver Wakjek menyediakan helm untuk penumpang/pelanggan 
1. Pernyataan nomor 29 yang menyatakan Perusahaan Wakjek selalu merespon dengan cepat keluhan dari pelanggan

m. Pernyataan nomor 30 yang menyatakan Anda yakin bahwa driver Wakjek menyediakan jas hujan

n. Pernyataan nomor 31 yang menyatakan Wakjek memasang tarif yang jelas dan murah sesuai dengan tujuan penumpang

o. Pernyataan nomor 32 yang menyatakan Keadaan motor yang dipakai Wakjek dalam keadaan baik dan bersih

Berdasarkan keterangan diatas dapat disimpulkan dimana kuadran A merupakan prioritas utama dimana responden merasakan atribut yang sangat penting tetapi merasakan tidak puas terhadap kinerja yang diberikan oleh pihak Wakjek, dalam kuadran A terdapat 15 item yang sangat penting tetapi responden masih merasa tidak puas terhadap kinerja dari ojek online Wakjek. Dengan rata-rata harapan nya berkisar pada $3.75-4.20$.

Untuk atiribut nomor 14 pelanggan Wakjek kurang merasakan kepuasan karena Wakejek tidak sepenuh nya melayani masyarakat saat dibutuhkan, Atribut 18 yang menyatakan masih kurang nya untuk masalah driver Wakjek memberikan sapaan dan senyuman saat awal bertemu penumpang, serta untuk atribut 19 dan 20 driver Wakjek pun ada beberapa yang berbicara kurang sopan seperti masih bersikap cuek maupun lainnya.

Masih kurang nya Wakjek untuk dapat diandalkan dalam mengantar penumpang dalam keadaan macet Di Kota Batam terlihat pada atribut 21, Masih terdengar nya isu negatife tentang layanan ojek online Wakjek ini tergambar pada atribut 23 , untuk atribut 24 dan 25 responden masih merasakan masih sulit nya menghubungi atau memesan ojek online Wakjek baik via telefon maupun online.

Driver Wakjek sendiri masih kurang dalam pengetahuan masalah rute-rute untuk tujuan pelanggan terlihat pada atribut 26 dan untuk atribut 27 masih kurang nya komunikasi yang sopan dari driver Wakjek. Untuk atribut 28 responden mengatakan masih ada driver Wakjek yang jarang memberikan helm kepada penumpangnya.

Serta untuk atribut 29, 30, 31, dan 32 responden masih merasakan pihak perusahaan masih kurang dalam menyikapi keluhan dari pelanggan, dan tariff ojek online Wakjek ini sendiri masih terbilang mahal dibandingkan tarif ojek online lainnya, dan untuk keadaan motor masih ada nya motor yang digunakan driver tidak dalam kondisi yang baik maupun bersih.

\section{Kuadran B (Pertahankan Prestasi)}

Kuadran ini menunjukkan atribut-atribut yang dianggap sangat penting oleh pelanggan dan telah dilaksanakan oleh perusahaan sesuai dengan harapan pelanggan. Atribut-atribut yang masuk pada kuadran ini harus tetap dipertahankan dan harus terus dikelola dengan baik, karena semua atribut ini menjadikan produk/jasa tersebut unggul di mata pelanggan Wakjek sehingga pada atribut ini wajib dipertahankan. Adapun atribut tersebut adalah:

a. Pernyataan nomor 13 yang menyatakan Driver memberikan respon cepat dengan mencari alternative jalan dalam kondisi macet dan terdekat

b. Pernyataan nomor 15 yang menyatakan Driver Wakjek mengemudi motor dengan hati-hati sehingga penumpang merasa aman

c. Pernyataan nomor 16 yang menyatakan Driver Wakjek dapat mengendarai dalam situasi hujan

d. Pernyataan nomor 17 yang menyatakan Driver Wakjek memahami dan mematuhi rambu-rambu lalulintas

e. Pernyataan nomor 33 yang menyatakan Kondisi motor Wakjek dalam keadaan baik sehingga nyaman untuk dinaiki

f. Pernyataan nomor 34 yang menyatakan Kelengkapan motor sesuai standar yang telah ditetapkan

g. Pernyataan nomor 35 yang menyatakan Driver selalu tampil bersih, rapi, harum dan wangi

Berdasarkan keterangan diatas dapat disimpulkan dimana kuadran B merupakan pertahankan prestasi dimana responden merasakan atribut yang sangat penting dan sangat memuaskan terhadap kinerja yang diberikan oleh pihak Wakjek sehingga pada atribut ini wajib dipertahankan, dalam kuadran B terdapat 7 item yang harus dipertahankan dan responden merasa puas dengan kinerja dari Wakjek 3,80-4,50.

Atribut 13 menyatakan driver memberikan respon cepat dengan mencari alternative jalan dalam kondisi macet dan terdekat atribut ini menunjukan bahwa driver memiliki respon yang cepat, untuk atribut 15 yang menyatakan Driver Wakjek mengemudi motor dengan hati-hati sehingga penumpang 
Yovan \& Shinta, Analisis Kepuasan Pelanggan...

merasa aman membuat responden mengatakan bahwa driver Wakjek tidak kebut-kebutan, untuk atribut 16 yang menyatakan Driver Wakjek dapat mengendarai dalam situasi hujan, responden merasa walaupun dalam kondisi hujan driver Wakjek tetap berhati-hati dalam mengendarai motornya, atribut 17 yang menyatakan Driver Wakjek memahami dan mematuhi rambu-rambu lalulintas membuat responden percaya karena driver Wakjek sangat mematuhi rambu-rambu lalulintas dan tidak ugal-ugalan.

Untuk atribut 33, 34, dan 35 menyatakan kelengakapan dan kondisi motor Wakjek telah sesuai standar yang ditentukan dan driver Wakjek selalu tampil bersih, rapi, harum dan wangi.

\section{Kuadran C (Prioritas Rendah)}

Pada kuadran ini merupakan prioritas rendah dimana responden merasakan kinerja yang rendah namun tidak terlalu diharapkan oleh pelanggan sehingga pihak Wakjek tidak perlu memprioritaskan atribut tersebut untuk dipebaiki. Adapun atribut tersebut adalah:

a. Pernyataan nomor 1 yang menyatakan Kemampuan driver untuk merespon order dari penumpang

b. Pernyataan nomor 2 yang menyatakan Driver tepat waktu sampai ketujuan pemesan

c. Pernyataan nomor 3 yang menyatakan Motor tidak mogok pada saat mengantar penumpang

d. Pernyataan nomor 4 yang menyatakan Driver melayani penumpang/pelanggan sesuai dengan SOP dari perusahaan Wakjek

e. Pernyataan nomor 5 yang menyatakan Aplikasi dari Wakjek mudah digunakan saat melakukan pemesanan

f. Pernyataan nomor 8 yang menyatakan Layanan operasional Wakjek 24 jam

g. Pernyataan nomor 12 yang menyatakan Driver mengantar pelanggan dengan cepat sampai ketujuan

Berdasarkan keterangan diatas dapat disimpulkan dimana kuadran $\mathrm{C}$ ini merupakan prioritas rendah dimana responden merasakan kinerja yang rendah namun tidak terlalu diharapkan oleh pelanggan sehingga pihak Wakjek tidak perlu memprioritaskan atribut tersebut untuk dipebaiki, dalam kuadran C terdapat 7 item yang dirasa kinerja nya sangat rendah mulai dari item $1,2,3,4,5,8,12$, namun pihak Wakjek tidak perlu memprioritaskan atribut tersebut untuk diperbaiki.

\section{Kuadran D}

Kuadran ini wilayah yang memuat atributatribut yang dianggap kurang penting oleh pelanggan dan kinerja yang dilakukan oleh pihak perusahaan dirasakan terlalu tinggi atau berlebihan. Adapun atribut tersebut adalah sebagai berikut:

a. Pernyataan nomor 6 yang menyatakan Jasa transportasi wakjek dapat diandalkan oleh masyarakat Batam

b. Pernyataan nomor 7 yang menyatakan Wakjek menjadi alternatife anda untuk sampai ketujuan pada saat situasi macet

c. Pernyataan nomor 9 yang menyatakan Driver merespon dengan cara mengkonfirmasi order dari pemesan melalui aplikasi

d. Pernyataan nomor 10 yang menyatakan Driver memberikan kesan positif saat bertemu dengan penumpang/pelanggan

e. Pernyataan nomor 11 yang menyatakan Driver menjawab pertanyaan pelanggan dengan baik

f. Pernyataan nomor 22 yang menyatakan Wakjek dapat diandalkan saat mengantar penumpang dalam situasi hujan

g. Pernyataan nomor 36 yang menyatakan Driver selalu menggunakan seragam yang mudah dikenali oleh pelanggan

h. Pernyataan nomor 37 yang menyatakan Driver selalu menggunakan helm saat mengendarai Wakjek untuk mengantar penumpang

i. Pernyataan nomor 38 yang menyatakan Jasa yang ditawarkan Wakjek sesuai ekspetasi pelanggan

j. Pernyataan nomor 39 yang menyatakan Kinerja driver Wakjek dilapangan sesuai SOP perusahaan

k. Pernyataan nomor 40 yang menyatakan Wakjek dapat diandalkan dalam menguranggi kemacetan

1. Pernyataan nomor 41 yang menyatakan Layanan Wakjek dapat diandalkan dalam jasa transportasi di Kota Batam

Berdasarkan keterangan diatas dapat disimpulkan dimana kuadran D ini merupakan menunjukkan atribut-atribut yang dianggap kurang penting oleh pelanggan, namun perusahaan telah melaksanakannya dengan baik, sehingga dianggap berlebihan. Atributatribut yang termasuk dalam kuadran ini dapat 
dikurangi, agar perusahaan dapat menghemat sumber daya, ada 12 item yang masuk ke dalam kuadran D.

\section{Pembahasan Penelitian}

Berdasakan hasil anaisis data yang telah penulis lakukan secara umum kepuasan pelayanan yang diberikan oleh ojek online Wakjek telah menunjukan hasil yang baik hal ini dapat dilihat dari tingkat kesesuaian yang ditunjukan oleh variabel $\mathrm{Y}$ yakni kepuasan pelayanan. Pada atribut kinerja nilai rata-rata variabel Y menunjukan angka 4,77 sedangkan ada atribut harapan nilai rata-rata variabel $\mathrm{Y}$ menunjukan angka 3,62. Hal ini berarti kepuasan pelayanan yang dirasakan oleh pelanggan ojek online Wakjek telah dapat memenuhi harapan dari pelanggan itu sendiri namun masih ada beberapa item yang perlu diperbaiki.

Dilihat dari kuadran A bahwa ada 15 item yang menjadi prioritas utama dimana responden merasakanatribut yang sangat penting tetapi merasakan tidak puas terhadap kinerja yang diberikan oleh pihak Wakjek. Item item tersebut tergambar pada diagram kartesius diatas. Untuk kuadran B ada 7 item merupakan pertahankan prestasi dimana responden merasakan atribut yang sangat penting dan sangat memuaskan terhadap kinerja yang diberikan oleh pihak Wakjek sehingga pada atribut ini wajib dipertahankan. Kuadran C merupakan prioritas rendah dimana responden merasakan kinerja yang rendah namun tidak terlalu diharapkan oleh pelanggan sehingga pihak Wakjek tidak perlu memprioritaskan atribut tersebut untuk dipebaiki ada 7 item pada kuadran $\mathrm{C}$ ini menunjukan bahwa pelanggan merasakan kinerja yang tidak terlalu diharapkan. Sedangkan kuadran D memiliki 12 item dengan tingkat kepentingan yang relatif rendah dan dirasakan oleh pengguna terlalu berlebihan dengan tingkat kepuasan yang relative tinggi. Hasil ini sejalan dengan penelitian terdahulu yang dilakukan oleh Irawati, Hati (2015)

\section{Kesimpulan}

Berdasarkan hasil penelitian yang telah dilakukan mengenai analisis kepuasan "Analisis Kepuasan Pelanggan Terhadap Kualitas Layanan Ojek Online (Wakjek) Di Kota Batam" dapat ditarik kesimpulan bahwa tingkat kepuasan pelanggan dari pelanggan ojek online Wakjek, dimana penulis menyebarkan kuesioner ke 100 responden Wakjek dengan karakteristik pengguna yang telah menggunakan Wakjek lebih dari 1 kali dalam 1 bulan ini. Adapun karakteristik responden untuk jenis kelamin kebanyakan reponden perempuan dengan tingkat persentase $52 \%$ dan laki-laki hanya $48 \%$, untuk karakteristik usia responden usia $17 \mathrm{~s} / \mathrm{d} 26$ lah yang banyak menggunakan ojek online Wakjek. Adapun untuk karakteristik pendidikan terakhir yang paling banyak adalah tamatan SMA/Sederajat, untuk karakteristik profesi yaitu profesi karyawan swasta yang paling banyak dengan tingkat persentase 35\%, dan untuk jenis layanan yang sering dipesan maupun digunakan adalah jenis pesan makanan dengan persentase $60 \%$.

Penulis juga menggunakan teknik Importance Peformance Analysis (IPA) menunjukan hasil bahwa pada kuadran A harus menjadi prioritas utama yang harus ditingkatkan karena memiliki tingkat kinerja / harapan tinggi dengan kinerja yang dinilai kurang, dalam kuadran ini ada 15 atribut yang dinilai kurang memuaskan yaitu atribut dengan kode no $14,18,19,20,21,23,24,25,26,27$, $28,29,30,31,32$ atribut-atribut ini harus menjadi acuan untuk perusahaan ojek online Wakjek untuk diperbaiki.

Kuadran B harus dipertahankan karena memiliki tingkat kinerja/harapan tinggi dengan tingkat kinerja yang dinilai tinggi, item ini terdapat pada atribut no $13,15,16,17,33,34$, 35 atribut-atribut ini harus dipertahankan oleh perusahaan Wakjek.

Untuk kuadran C termasuk prioritas rendah karena memiliki tingkat kinerja/harapan terhadap atribut kualitas pelayanan dinilai tidak penting dan kinerja nya dinilai kurang ini terdapat pada atribut no 1, 2, 3, 4, 5, 8, 12

Sedangkan untuk kuadran D ini menunjukkan atribut-atribut yang dianggap kurang penting oleh pelanggan, namun perusahaan telah melaksanakannya dengan baik, sehingga dianggap berlebihan. Atributatribut yang termasuk dalam kuadran ini dapat dikurangi, agar perusahaan dapat menghemat sumber daya, adapun item nya sebanyak 12 item yang tedapat di kuadran D adalah no 6,7 , $9,10,11,22,36,37,38,39,40,41$.

Berdasakan hasil anaisis data yang telah penulis lakukan secara umum kepuasan pelayanan yang diberikan oleh ojek online Wakjek telah menunjukan hasil yang baik hal ini dapat dilihat dari tingkat kesesuaian yang 
Yovan \& Shinta, Analisis Kepuasan Pelanggan...

ditunjukan oleh variabel $\mathrm{Y}$ yakni kepuasan pelayanan. Pada atribut kinerja nilai rata-rata variabel Y menunjukan angka 4,77 sedangkan ada atribut harapan nilai rata-rata variabel $\mathrm{Y}$ menunjukan angka 3,62. Hal ini berarti kepuasan pelayanan yang dirasakan oleh pelanggan ojek online Wakjek telah dapat memenuhi harapan dari pelanggan ojek online Wakjek itu sendiri namun masih ada beberapa item yang harus diperbaiki

\section{Saran}

Berdasarkan pembahasan yang diperoleh dari penelitian ini, maka diajukan saran-saran sebagai pelengkap mengenai analisis kepuasan "Analisis Kepuasan Pelanggan Terhadap Kualitas Layanan Ojek Online (Wakjek) Di Kota Batam" adalah sebagai berikut:

1. Penelitian ini diharapkan mampu memberikan kontribusi kepada perusahaan agar terus diperbaiki kualitas dari pelayanan yang diberikan kepada pelanggan. Secara berkelanjutan akan bermanfaat terhadap perusahaan untuk menghadapi persaingan global saat ini dan dimasa yang akan datang.

2. Agar pihak Wakjek lebih memperhatikan kinerjanya karena pada kuadran A harus menjadi prioritas utama yang harus ditingkatkan karena memiliki tingkat kinerja / harapan tinggi dengan kinerja yang dinilai kurang, dalam kuadran ini ada 15 atribut yang dinilai kurang memuaskan yaitu atribut dengan kode no $14,18,19,20,21,23,24,25,26,27,28$, $29,30,31,32$ atribut-atribut ini harus menjadi acuan untuk perusahaan ojek online Wakjek untuk diperbaiki.

3. Serta harus mempertahankan item yang berada pada Kuadran B dikarenaka ada 7 atribut yang harus perusahaan Wakjek pertahankan agar kepuasan pelanggan terus tercipta.

4. Untuk kuadran $\mathrm{C}$ maupun kuadran D perusahaan juga harus memperhatikan nya tetapi tidak harus memperbaiki karena kuadran C maupun D tidak wajib untuk diperbaiki.

5. Memberikan masukan kepada perusahaan agar lebih peka terhadap masalah kualitas pelayanan.

\section{DAFTAR PUSTAKA}

Dwiwinasrsih; Rina. (2009). Analisis Tingkat kepuasan Konsumen Terhadap Pelayanan
Bakmi Aisy di Depok. Fakultas Ekonomi Universitas Gunadarma .Public Relations" di Provinsi Banten. MediaTor, 9(2), 393402.

Fonseca, Filipa; Pinto, Sofia; Brito, Carlos. (2010). Service Quality and Customer Satisfacation In Public Transports. International Journal For Quality Research, UDK- 656.025.2:658.56 Short Scentific Paper (1.03).

Hamid, Fortuna Zain; Siambota, Ernita. (2010). Pengarus Kualitas Pelayanan Jasa Terhadap Keputusan Pembelian Pada Pengguna Jasa Ojek Online Go-jek. Administrasi Bisnis Terapan Poiteknik Negeri Jakarta .

Hati, S.W., Irawati, R., \& Wirangga, A. (2014). Motivasi Kerja Terhadap Kondisi Sosial ekonomi Tenaga Kerja Wanita di Sektor Industri. Proceeding Applied Business and Engineering Conference (ABEC)

Irawati, Rusda; Hati, Shinta Wahyu. (2015). Survei Kepuasan Pelanggan Pelabuhan Penyebrangan Domestik Sekupang. Jurusan Manajemen Bisnis, Politeknik Negeri Batam .

Jahanshasi, Asghar Afsar; Gashti, Mohammad Ali Hajizadeh; Mirdamadi, Sayed Abbas; Nawaser, Khaled; Khaksar, Seyed Mohammad Sadeq. (2011). Study The Effects of Customer Service and Product Quality On Customer Satisfaction and Loyalty. International Journal of Humanities and Social Science, Vol 1 No 7.

Jasfar, Farida. 2009. Manajemen Jasa. Ciawi, Bogor: Ghalia Indonesia.

Kotler, P., \& Keller, K. (2009). Marketing management (13th ed.). New Jersey : Prentice Hall, Inc.

Ravichandran, K.; Mani, B. Tamil; Kumar, S. Arum; Prabhakaran, S. (2010). Influnce of Service Quality on Customer Statisfacation Application of Servqual Model. International Journal of Business and Management, Vol 5 No 4. 
Journal of Applied Business Administration Vol 1, No 1, Maret 2017, hlm. 96-121

Sugiyono. (2013). Metode Penelitian Kuantitatif, Kualitatif dan $R \& D$. Bandung: Alfabeta.

Sunyoto, Danang; Susanti, Fatonah Eka. (2015). Manajemen Pemasaran Jasa. Jogyakarta.

Umar, Z. A. (2012, Maret). Strategi bauran pemasaran dalam meningkatkan volumen penjualan ikan tuna olahan pada PT Betel Citra Seyan Gorontalo. Jurnal INOVASI, 9(1), 1-2 